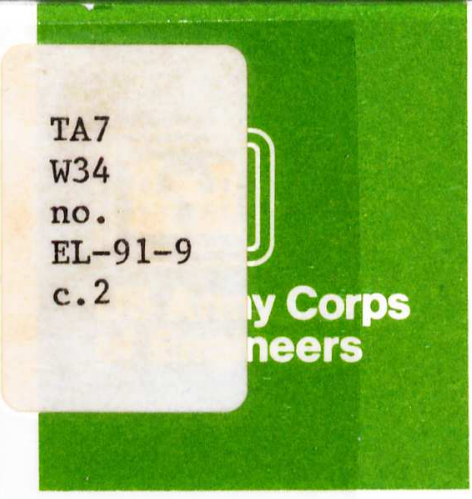

\title{
INVESTIGATION OF FRESHWATER MUSSELS (UNIONIDAE) AT SELECTED SITES IN THE LOWER OHIO AND CUMBERLAND RIVERS, SEPTEMBER 1990
}

\author{
by \\ Andrew C. Miller, Barry S. Payne \\ Environmental Laboratory \\ DEPARTMENT OF THE ARMY \\ Waterways Experiment Station, Corps of Engineers \\ 3909 Halls Ferry Road, Vicksburg, Mississippi 39180-6199

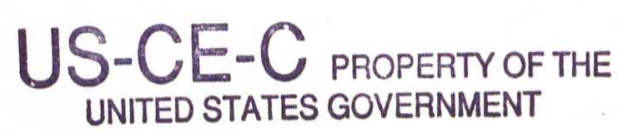 \\ UNITED STATES GOVERNMENT
}
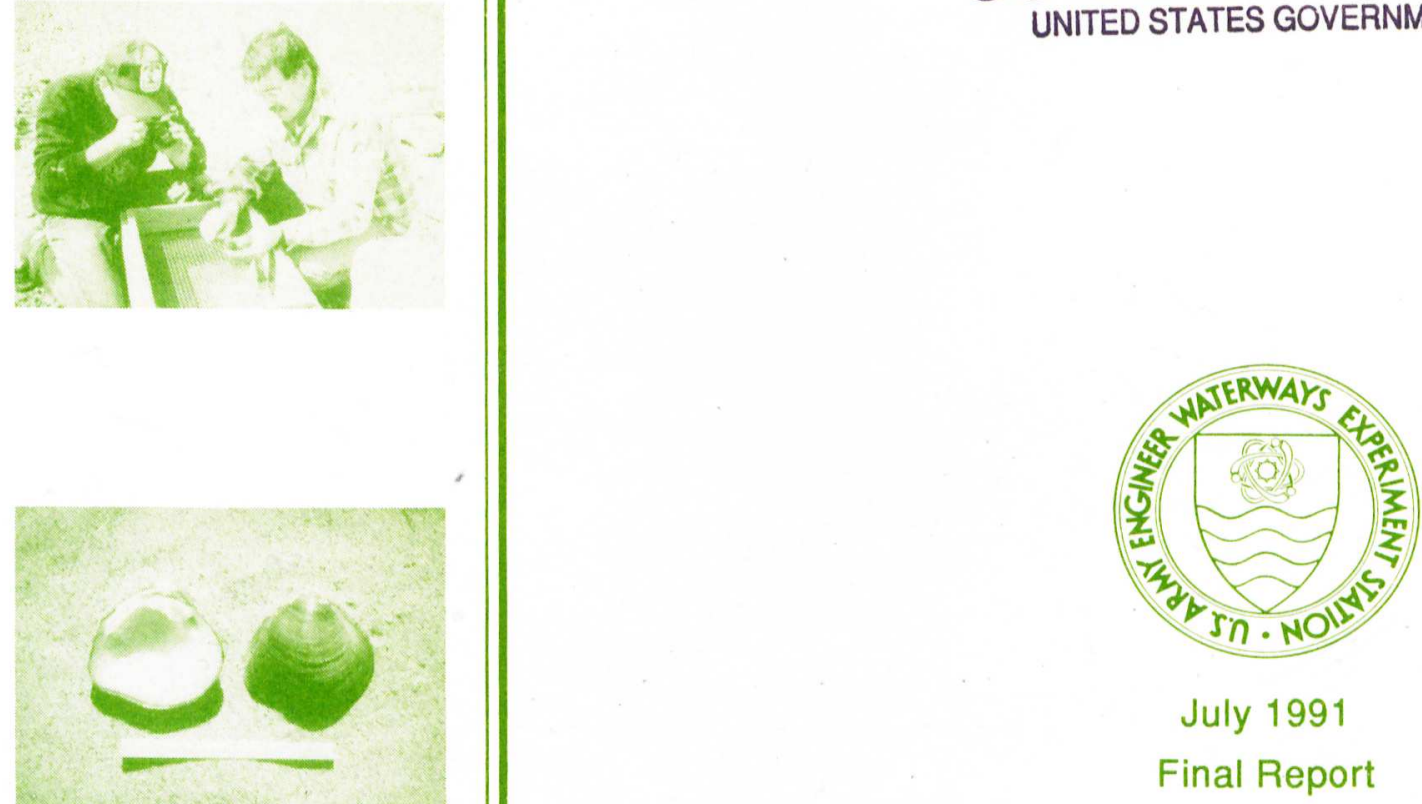

Approved For Public Release; Distribution Unlimited

RESEARCH LIBRARY

US ARMY ENGINEER WATERWAYS

EXPERIMENT STATION

VICKSBURG, MISSISSIPPI

Prepared for US Army Engineer District, Louisville Louisville, Kentucky 40201-0059 
Destroy this report when no longer needed. Do not return it to the originator.

The findings in this report are not to be construed as an official Department of the Army position unless so designated by other authorized documents.

The contents of this report are not to be used for advertising, publication, or promotional purposes. Citation of trade names does not constitute an official endorsement or approval of the use of such commercial products. 
Public redorting burden tor inis collection of intormation is estimated to average I nour der resoonse. inciuding the time for reviewing instructions. searening existing data sources. gathering and maintaining the dats needed. and comoleling and reviewing ine collection of intormation. Send comments regarding this burden estimate or anv other aspect of this

\begin{tabular}{|l|c|c|}
\hline 1. AGENCY USE ONLY (Leave blank) & $\begin{array}{r}\text { 2. REPORT DATE } \\
\text { July } 1991\end{array}$ & $\begin{array}{r}\text { 3. REPORT TYPE AND } \\
\text { Final redort }\end{array}$ \\
\hline
\end{tabular}

4. TITLE AND SUBTITLE

July 1991

5. FUNDING NUMBERS

Investigation of Freshwater Mussels (Unionidae) at Selected Sites in the

Lower Ohio and Cumberland Rivers, September 1990

6. AUTHOR(S)

Andrew C. Miller

Barry S. Payne

7. PERFORMING ORGANIZATION NAME(S) AND ADDRESS(ES)

USAE Waterways Experiment Station, Environmental Laboratory

3909 Halls Ferry Road, Vicksburg, MS 39180-6199

8. PERFORMING ORGANIZATION

REPORT NUMBER

Technical Report EL-91-9

9. SPONSORING/MONITORING AGENCY NAME(S) AND ADDRESS(ES)

US Army Engineer District, Louisville

PO Box 59, Louisville, KY 40201-0059

10. SPONSORING /MONITORING AGENCY REPORT NUMBER

\section{SUPPLEMENTARY NOTES}

Available from National Technical Information Service, 5285 Port Royal Road, Springfield, VA 22161

12a. DISTRIBUTION/AVAILABILITY STATEMENT

12b. DISTRIBUTION CODE

Approved for public release; distribution unlimited

13. ABSTRACT (Maximum 200 words)

A survey to assess community characteristics, density, population demography of dominant species, and the likelihood of finding endangered species of freshwater mussels (Unionidae) was conducted in the lower Ohio River (river miles (RM) 954.0-964.0), the lower two miles of the Cumberland River, and a reach of the Ohio River (RM 920.0-920.5) near Smithland Dam in September 1990. Data will be used to analyze impacts of construction and operation of a new lock and dam at RM 964.4 on the Ohio River and modification of Smithland Lock and Dam near the confluence of the Cumberland River. Twenty-three species of unionids were collected using qualitative methods in the lower Ohio River; the fauna was dominated by Fusconaia ebena (40.9 percent), Quadrula pustulosa pustulosa (10.76 percent), Quadrula quadrula (10.6 percent), and Amblema plicata plicata (9.0 percent). Species diversity $\left(\log _{2.3026}\right)$ ranged from 1.19 to 2.27 , and evenness ranged from 0.45 to 0.82 . Total unionid density ranged from 37.6 to 68.0 individuals/sq $\mathrm{m}$, and Corbicula fluminea density ranged from 11.2 to 26.8 individuals/sq $\mathrm{m}$. Four specimens of the orange-footed pimpleback (Plethobasus cooperianus), listed as endangered by the US Fish and Wildlife Service (1987), were collected (two using qualitative methods; two using quantitative methods). Twelve species of common mussels, not including endangered or unusual species, were found at ten sites in the lower Cumberland River and the Ohio River near Smithland Lock and Dam.

14. SUBJET TERMS

Environmental impacts

Freshwater molluscs

\begin{tabular}{|c|c|c|c|}
\hline $\begin{array}{l}\text { 17. SECURITY CLASSIFICATION } \\
\text { OF REPORT }\end{array}$ & $\begin{array}{l}\text { 18. SECURITY CLASSIFICATION } \\
\text { OF THIS PAGE }\end{array}$ & $\begin{array}{l}\text { 19. SECURITY CLASSIFICATION } \\
\text { OF ABSTRACT }\end{array}$ & 20. LIMITATION OF ABSTRACT \\
\hline UNCLASSIFIED & UNCLASSIFIED & & \\
\hline
\end{tabular}





\section{Contents}

Preface $\ldots \ldots \ldots \ldots \ldots \ldots \ldots \ldots$

Conversion Factors, Non-SI to SI

Units of Measurement ................. vii

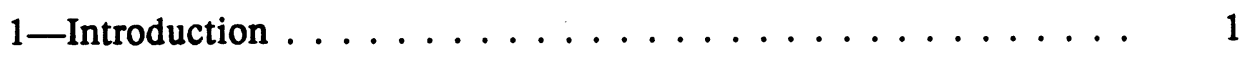

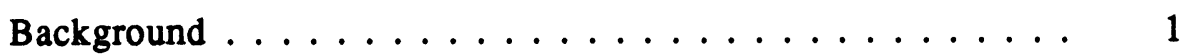

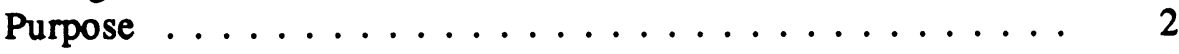

2 -Study Area and Methods $\ldots \ldots \ldots \ldots \ldots$

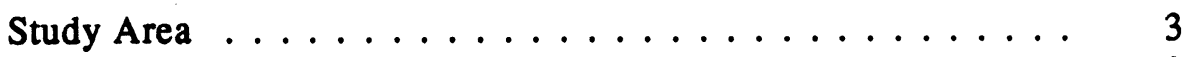

Methods ...................... 3

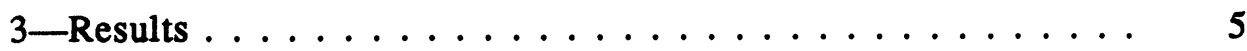

Unionid Community Characteristics . . . . . . . . . . . 5

Bivalve Density ........................ 6

4-Characterization of the Bivalve Community $\ldots \ldots \ldots$

The Unionid Assemblage . . . . . . . . . . . . . . . 9

The Presence of $C$. fluminea . . . . . . . . . . . . . 9

Species Richness . . . . . . . . . . . . . . . . . . . . 10

Relative Species Abundance . . . . . . . . . . . . . 10

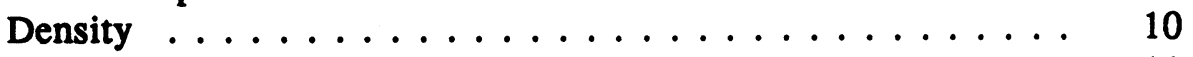

The Presence of Endangered Species ............ 11

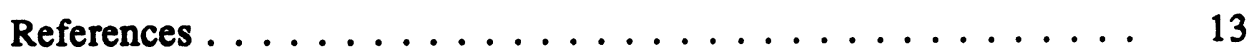

Figures 1-12

Tables 1-6

Appendix A: Freshwater Mussels of the Lower Ohio River $\ldots . . \quad$ A1 



\section{Preface}

A mollusc survey was conducted by the US Army Engineer Waterways Experiment Station (WES) on 22-24 September 1990, for the US Army Engineer District, Louisville (CEORL), Louisville, KY. The purpose was to investigate a reach on the lower Ohio River that could be affected by construction and operation of Olmsted Lock and Dam, and a reach of the lower Cumberland River that could be affected by modifications to Smithland Lock and Dam. Information from these surveys will be used by CEORL to prepare environmental assessments describing proposed actions.

Divers were Larry Neill, Mitchell Marks, Steve McKinny, and Dennis Baxter from the Tennessee Valley Authority. Assistance in the field was provided by Dr. Bill Pearson, Water Resources Laboratory at the University of Louisville, Louisville, KY, and by Ms. Jennifer Marsh and Mr. David Marsh, University of Louisville. Mr. Mike Turner, CEORL, monitored the contract and assisted in the field. This report was edited by Ms. Janean Shirley of the Information Technology Laboratory, WES.

During the conduct of this study Dr. John Harrison was Chief, Environmental Laboratory (EL), WES, Dr. C. J. Kirby was Chief, Environmental Resources Division, EL, WES, and Dr. E. Theriot was Chief of the Aquatic Habitat Group, EL, WES. Authors of this report were Dr. Andrew C. Miller and Dr. Barry S. Payne, WES.

Commander and Director of WES during publication of this report was COL Larry B. Fulton, EN, and the Technical Director was Dr. Robert W. Whalin.

This report should be cited as follows:

Miller, Andrew C., and Payne, Barry S. 1991. "Investigation of Freshwater Mussels (Unionidae) at Selected Sites in the Lower Ohio and Cumberland Rivers, September 1990," Technical Report EL-91-9, US Army Engineer Waterways Experiment Station, Vicksburg, MS. 


\section{Conversion Factors, Non-SI to SI Units Of Measurement}

Non-SI units of measurement used in this report can be converted to SI units as follows:

\begin{tabular}{|l|l|l|}
\hline Multiply & By & To Obtain \\
\hline feet & 0.3048 & meters \\
\hline miles (US nautical) & 1.852 & kilometers \\
\hline
\end{tabular}





\section{Introduction}

\section{Background}

The continued use of inland waterways to transport bulk commodities (Dietz et al. 1983) has caused planners and biologists in government agencies to express concern over the possible negative effects of movement of commercial vessels in inland waterways (Rasmussen 1983). The physical effects of commercial vessel movement include wave wash, turbulence, benthic scour, drawdown, current reversals, and periods of increased sediment resuspension (Wright 1982). In addition, secondary effects of increased navigation traffic, such as lock and dam construction or modification, dredging, and water level manipulation, also have the potential for negatively affecting aquatic biota. Freshwater mussels, a resource with economic, ecological, and cultural value, could be affected by these disturbances. Their sedentary lifestyle and reliance on suspended particulate organic matter make them susceptible to turbulence, sedimentation, and fluctuating water levels.

Although physical effects of waterway alteration can be simulated in the laboratory, caution must be exercised when using results of these studies to estimate impacts to natural populations. Responses studied in the laboratory may not occur in the field. In addition, naturally occurring compensatory mechanisms, which are not part of laboratory experiments, usually exist. Biologists should evaluate the effects of man's activities on populations of species in their natural habitats. As an alternative to laboratory simulation, field studies should be conducted to evaluate the biological effects of water resource developments. These studies must be designed to provide quantitative data on biotic parameters, such as density, relative species abundance, community composition, population demography, and rate of growth, of naturally occurring populations. These data cannot be obtained with exploratory devices such as the brail, or qualitative collections by hand (Miller and Payne 1988). Quantitative total substrate samples provide the type of data required to measure the overall health and ultimate survival of a mussel community.

The US Army Engineer District, Louisville (CEORL) requested that personnel from the US Army Engineer Waterways Experiment Station 
(WES) conduct a survey of freshwater mussels (Family: Unionidae) at two areas likely to be affected by proposed water resource developments. A reach on the lower Ohio River (LOR) will be affected by construction and operation of Olmsted Lock and Dam, to be located at river mile ${ }^{1}$ (RM) 964.4 on the Ohio River. Concern has been expressed that construction and operation of the dam could affect a dense and diverse mussel bed first identified by Williams (1969) between RM 966.0 and 969.2. In addition, CEORL proposes to alter Smithland Locks and Dam, located at RM 918.5. Proposed modifications to the fixed weir on the left descending bank (LDB) could affect flow in the old channel line immediately downriver as well as the lower Cumberland River.

\section{Purpose}

The purpose of this study was to describe community composition, density, areal extent, recruitment rates, and presence of endangered species of freshwater mussels at selected sites in the lower Ohio and lower Cumberland Rivers.

\footnotetext{
1 A table of factors for converting non-SI units of measurement to SI (metric) units is presented on page vii.
} 


\section{Study Area and Methods}

\section{Study Area}

In the LOR near Olmsted, IL, quantitative samples were collected at RM 967.2 (Site Q1) and 966.5 (Site Q2, see Figure 1 and Table 1).

Qualitative collections were made at four sites: RM 957.8 (Sites 1 and 2), RM 963.8 (Site 3), and RM 967.2 (Site 4). In addition, divers intensively searched a series of sites along the LDB immediately up- and downriver of Lock and Dam 53. Ten areas were intensively searched for mussels downriver of Smithland Lock and Dam (Figure 2).

\section{Methods}

\section{Preliminary reconnaissance}

All underwater work was accomplished by a dive crew equipped with surface air supply and communication equipment. Before intensive sampling was initiated, a single diver conducted a preliminary survey. He obtained information on substrate type, water velocity, and presence of mussels. Qualitative sampling was initiated if the substrate appeared stable and if there was moderate to high mussel density (i.e.; greater than 3-5 individuals/sq $\mathrm{m}$ ).

\section{Qualitative mussel collections}

The majority of the qualitative samples were obtained by having three divers collect simultaneously. Each diver placed a specific number of live mussels in each of four nylon bags; five mussels were placed in the first bag and 20 were placed in each of the other three bags. The divers were instructed to obtain mussels without bias toward size or type. They attempted to exclude the Asiatic clam, Corbicula fluminea. If $C$. fluminea was inadvertently collected, it was later eliminated. All mussels were brought to the surface, counted, and identified. Data were recorded on 
standard data sheets and returned to WES for analysis and plotting. Shells of voucher specimens for each species were placed in plastic zipper-lock bags and labeled with high-rag-content paper. Mussels not needed for voucher were returned to the river. Methods for sampling mussels are based on techniques described in Coker (1919); Brice and Lewis (1979); Miller and Nelson (1983); Isom and Gooch (1986); Kovalak, Dennis, and Bates (1986); and Miller and Payne (1988). Mussel identification was based on taxonomic keys and descriptive information in Murray and Leonard (1962); Parmalee (1967); Starrett (1971); and Burch (1975).

\section{Quantitative mussel collections}

Quantitative samples (that included unionids as well as $C$. fluminea), were obtained at RM 966.5 and RM 967.2 in the LOR. At each site, either 5 or 10 quadrats $(0.25 \mathrm{sq} \mathrm{m})$ were positioned approximately $1 \mathrm{~m}$ apart and arranged in a 2 by 2 or a 2 by 5 matrix. A diver excavated all sand, gravel, shells, and live clams to a depth of $10-15 \mathrm{~cm}$. Material was sent to the surface in a 20-L bucket and transported to shore. Sediment was screened through a sieve series (finest screen with apertures of $6.4 \mathrm{~mm}$ ). All live mussels and $C$. fluminea removed from samples were placed in 4-L zipper-lock bags. Each bivalve was then identified and total shell length (SL) measured to the nearest $0.1 \mathrm{~mm}$ with dial calipers.

\section{Data analysis}

Species diversity was determined with the following formula:

$$
H^{\prime}=-p_{j} \log p_{j}
$$

where $p_{j}$ is the proportion of the population that is of the jth species (Shannon and Weaver 1949). All calculations were performed with programs written in BASIC or SAS (Statistical Analytical System) on an IBM $\mathrm{XT}$ or AT personal computer. Discussion of statistical procedures that were used can be found in Green (1979) and Hurlbert (1984). Species area curves and dominance-diversity curves were constructed from qualitative and quantitative biological data. More information on methods used for this survey can be found in McNaughton and Wolf (1973); Isom and Gooch (1986); Kovalak, Dennis, and Bates (1986); Hughes (1986); and Miller and Payne (1988). 


\section{Results}

\section{Unionid Community Characteristics}

Twenty-three species of freshwater mussels (Family: Unionidae) were collected using qualitative methods at RM 957.8, 963.8, and 967.2 in the LOR on 22-25 September, 1990 (Table 2). The fauna was dominated by Fusconaia ebena (40.9 percent), Quadrula pustulosa pustulosa (10.76 percent), Quadrula quadrula (10.6 percent), and Amblema plicata plicata (9.0 percent). Fusconaia ebena was approximately four times as abundant as the latter three species; together these four species comprised 71.4 percent of the fauna. Eleven species were considered uncommon and comprised less than 1 percent of the assemblage. The native fauna was dominated by thick or moderately thick-shelled species. Leptodea fragilis comprised only 0.24 percent of the collection, and other thin-shelled species (Anodonta grandis and Anodonta imbecillis) usually associated with fine sand or silt substratum, were not found. A plot of species rank versus percent abundance for the total qualitative collection (Figure 3) illustrates the strong dominance of $F$. eben $a$ and the relatively even distribution of the remaining mussels in the assemblage.

Two specimens of the orange-footed pimpleback (Plethobasus cooperianus), listed as endangered by the US Fish and Wildlife Service (1987) were collected qualitatively. One individual was found at RM 957.8 (500 $\mathrm{ft}$ from the right descending bank (RDB)), and one was found at RM 967.2 (700 ft from the RDB, see Table 3). Although this species is listed as endangered, it was not the least common in the collection. Only a single specimen was found of the following species: Actinonaias ligamentina, Ligumia recta, and Plethobasus cyphus (Table 2).

In these qualitative collections Fusconaia ebena was more abundant in samples taken at farshore as opposed to nearshore sites (Figure 4). Amblema plicata was consistently more common in nearshore as compared with farshore sites. Three other species (Quadrula pustulosa, Quadrula quadrula, and Megalonaias nervosa) did not exhibit any strong or consistent nearshore/farshore trends. Species diversity $\left(\log _{2.3026}\right)$, based on a sample of approximately 200 individuals at each of the four sites, ranged from 1.19 to 2.27 , and evenness ranged from 0.45 to 0.82 
(Table 3). The low diversity and evenness at RM 967.2 were primarily the result of extreme dominance of a single species, $F$. ebena. Conversely, the high values at RM 957.8 ( $350 \mathrm{ft}$ from the RDB) were the result of the fairly even distribution of three dominant species ( $F$. ebena, $Q$. pustulosa, and $A$. plicata) (Table 3 ).

The most abundant bivalve, $F$. ebena, was taken in 95.8 percent of the 48 qualitative samples (Tables 2 and 4). Two species that were about 25 percent as common as $F$. ebena, $Q$. pustulosa, and $Q$. quadrula were taken in 33.3 to 91.7 percent of the samples (Table 4). Approximately half of the mussels collected at each site using qualitative methods were taken in only 1 or 2 of the 12 samples. A plot of cumulative species versus cumulative individuals collected qualitatively illustrates the relationship between sampling effort and the ability to find uncommon species (Figure 5). After 400 individuals had been collected, 22 species had been identified. After approximately 200 additional individuals were collected only 1 more new species was found. Based on these results it appears unlikely that additional species would be found with more sampling effort. If a rare species were present and not collected, it would have comprised less than 0.12 percent of the assemblage (Table 2).

\section{Bivalve Density}

Total unionid densities were moderate and ranged from 37.6 to 68.0 individuals/sq $\mathrm{m}$ (Table 5 and Figure 6) at two locations in the LOR. Corbicula fluminea densities ranged from 11.2 to 26.8 individuals/sq $\mathrm{m}$. Fusconaia ebena was strongly dominant at RM 967.2 (60.4-62.8 percent of the assemblage), and less common (48.2-58.2 percent) at RM 966.5. The high dominance of $F$. ebena in the total quantitative collection is displayed graphically in Figure 7a. The second-most-abundant species in the quantitative collection ( $Q$. pustulosa) comprised only 10 percent of the assemblage. This species, unlike $F$. ebena, was most common at RM 966.5. The relationship between cumulative species and cumulative individuals in the quantitative collection is depicted in Figure $7 \mathrm{~b}$. The relationship between cumulative species and cumulative individuals was similar regardless of whether mussels were collected qualitatively or quantitatively. After 400 individuals had been collected, 22 species had been identified (compare Figures 5 and $7 \mathrm{~b}$ ).

\section{Demographic analysis of dominant bivalve populations}

Fusconaia ebena. Although Fusconaia ebena spanned the SL range of 30 to $92 \mathrm{~mm}, 81$ percent of the sample was comprised of individuals between 48 and $64 \mathrm{~mm} \mathrm{SL}$ (Figure 8a). Previous work has established that these mussels from 48-64 mm SL represent an exceptionally abundant year class of 1981 recruits (Payne and Miller 1989). Sampling in the fall 
of 1983 established that the 1981 year class of recruits represented approximately 70 percent of the total population. The single year class had an average SL of $16 \mathrm{~mm}$ in 1983 . Subsequent sampling indicated that this cohort achieved an average SL of $56 \mathrm{~mm}$ by the fall of 1990 . The growth of the 1981 cohort is summarized in Figure 8b. Furthermore, from 1983 to the present there has been no indication of strong recruitment to this population. The paucity of mussels less than $40 \mathrm{~mm} \mathrm{SL}$ in Figure $8 \mathrm{a}$ indicates that little recent recruitment has occurred.

Ellipsaria lineolata. The relatively small sample $(\mathrm{n}=16)$ of this population did not allow detailed analysis of size demography. Individuals spanned the SL range of 44 to $88 \mathrm{~mm}$ (Figure 9).

Quadrula pustulosa. Quadrula pustulosa ranged from 4 to $62 \mathrm{~mm} \mathrm{SL}$, but the sample was not sufficiently large $(n=17)$ for detailed analysis of size demography. Only two individuals were less than $34 \mathrm{~mm}$ SL; these two mussels were recent recruits measuring only 4-8 mm SL (Figure 10).

Corbicula fluminea. The population of the Asiatic clam exhibited clear differences in size structure of farshore (Figure 11a) versus nearshore (Figure 11b) locations. Samples collected $700 \mathrm{ft}$ from shore at a depth of $14 \mathrm{ft}$ were dominated by small recruits ranging in SL from 6 to $14 \mathrm{~mm}$ (these individuals were probably recruited in spring 1990). Only 12 of the 67 individuals collected at the farshore site were greater than $22 \mathrm{~mm}$ SL (recruits of 1989 or earlier). In contrast, all of the 28 individuals collected at the nearshore site $(230-300 \mathrm{ft}$ from the shore at a depth of 14-15 ft) were less than $12 \mathrm{~mm} \mathrm{SL}$.

\section{Cumberland River}

Mussels were either absent or present in low densities at 10 sites in the lower Cumberland River or RDB of the Ohio River near Smithland Lock and Dam (Table 6 and Figure 12). Twelve species of unionids were found at Site 8; the assemblage was dominated by $Q$. quadrula (38.7 percent) and $F$. ebena (16.1 percent). Further downriver, $30 \mathrm{~min}$ of searching yielded four species and eight individuals. Eight species and thirty-five live mussels were collected in $\mathbf{3 0}$ min of searching on the dike. The fauna was dominated by $Q$. quadrula (51.4 percent) and A. plicata (20.0 percent).

Intensive searches in this reach of the river yielded no unusual or endangered species of mussels. Special effort was directed toward Potamilus capax, reported in the channel between Cumberland Island Towhead and the Kentucky shore. No specimens of $P$. capax were found in the lower Cumberland River or the reach of the Ohio River immediately below Smithland Lock and Dam. 



\section{Characterization of the Bivalve Community}

\section{The Unionid Assemblage}

The mussel assemblage in the LOR and lower Cumberland River consisted almost entirely of thick-shelled species. The fauna was dominated by $F$. ebena, A. plicata, and Quadrula spp., with lesser numbers of Elliptio spp., $M$. nervosa, and $P$. cordatum. Thin- and moderately thick-shelled species ( $L$. fragilis, $P$. alatus, and Anodonta spp.) were either uncommon or absent at sites sampled in both rivers. Within their range, these thinshelled species are found in appropriate substrate in large rivers. Each species has multiple fish hosts (Fuller 1974) and would be more common at these sites if suitable conditions of substrate and water velocity existed. However, coarse gravel substrate and erosive flows at high discharge will stress thin-shelled species. If present, few are likely to reach adult size. This mussel assemblage would probably support more thin-shelled species if average water velocities were less and sediments contained a higher percentage of silt and sand.

\section{The Presence of C. fluminea}

Williams (1969) sampled the LOR with an 8-ft brail and a Petersen dredge. Based on quantitative samples, he estimated that $C$. fluminea comprised about 35 percent of the bivalve community, although no density estimates were provided. In the present survey, $C$. fluminea density ranged from 11.2 to 161.6 individuals/sq $\mathrm{m}$ (Table 5 and Figure 6). Based on these data it appears that $C$. fluminea densities are similar to those reported by Williams (1969). However, because this species does not require an intermediate fin-fish host and has a comparatively short life span, its densities and population structure can fluctuate extensively in response to physical disturbance. 


\section{Species Richness}

Total species richness in the LOR is similar to that at other mussel beds in large rivers. In a survey of the upper Mississippi River conducted in 1989, Miller et al. (1990) collected over 15,000 bivalves in 667 qualitative samples at 58 locations and identified 34 species. However, total species richness at any one location was usually between 15 and 25. Smaller rivers usually support fewer species. Using quantitative techniques at dense beds in the Sunflower River and Big Black River in central Mississippi, 13 and 15 species were identified, respectively (Miller and Hartfield; Payne and Miller, unpublished information).

Species richness has not changed recently in this reach of the LOR. In 1988, Payne and Miller (1989) collected 23 species of freshwater mussels at sites along the RDB in the mussel bed below Lock and Dam 53.

\section{Relative Species Abundance}

The fauna in this mussel bed is characterized by moderate to low evenness. Evenness can range from near 0.0 to near 1.0; at these sites values ranged from 0.45 to 0.79 . Low evenness was the result of the relatively high abundance of the dominant unionid $F$. ebena (21.1 to 70.2 percent, Table 3). Based on similar qualitative collections at six sites in a dense and diverse mussel bed in the Ohio River near Cincinnati, OH, evenness ranged from 0.756 to 0.817 (Miller and Payne 1991).

\section{Density}

In comparison with other large-river mussel beds, the range in unionid density ( 37.6 to 68.0 individuals/sq $\mathrm{m}$ ) can be considered low to moderately high. At an inshore and offshore sites in the lower Tennessee River at RM 18.6 on the LDB (32 quantitative samples were collected at each site) total mussel density was 187.7 and 79.7 individuals/sq $\mathrm{m}$, respectively (Way, Miller, and Payne 1989). In a survey of the upper Mississippi River, Miller et al. (1990) reported that total mussel density ranged from 5.2 to 333.2 individuals/sq $\mathrm{m}$ at 16 sites ( 10 quantitative samples were taken at each site). At half of the sites total density was greater than 50 individuals/sq $\mathrm{m}$ and at 4 sites it was greater than 100 individuals/sq $\mathrm{m}$. In the Big Black River in central Mississippi, unionid density was 84.4 and 112.0 individuals/sq $\mathrm{m}$ at the upstream and downstream slopes of a gravel shoal, respectively (Payne and Miller, unpublished information). 


\section{The Presence of Endangered Species}

Miller, Payne, and Siemsen (1986) collected P. cooperianus at this bed in the fall of 1983 . In the present survey, 818 mussels were collected using qualitative techniques. After 400 individuals had been taken, 22 species had been identified; collecting an additional 200 individuals yielded 1 more species. The relationship between cumulative species and cumulative individuals (Figure 5), indicates that it would be unlikely to collect many more species. However, since two specimens of the endangered $P$. cooperianus were collected (using qualitative methods) in this survey, such additional sampling would not be required. It is apparent that $P$. cooperianus continues to exist in specific reaches of the LOR in densities high enough to be easily collected. 



\section{References}

Brice, J., and Lewis, R. 1979. "Mapping of Mussel (Unionidae) Communities in Large Streams," American Midland Naturalist, Vol 101, pp 454-455.

Burch, J. B. 1975. "Freshwater Unionacean Clams (Mollusca: Pelecypoda) of North America," Malacological Publications, Hamburg, MI.

Coker, R. E. 1919. "Fresh-Water Mussels and Mussel Industries of the United States," Bulletin of the United States Bureau of Fisheries, Vol 13, pp 75-181.

Dietz, A. R., Harrison, R. W., Olson, H. E., Grier, D., and Simpkins, C. 1983. "National Waterways Study-A Framework for Decision Making-Final Report," Report NWS-83-1, US Army Engineer Institute for Water Resources, Water Resources Support Center, Fort Belvoir, VA.

Fuller, S. L. H. 1974. "Clams and Mussels (Mollusca: Bivalvia)," Pollution Ecology of Freshwater Invertebrates, C. W. Hart, Jr., and S. L. H. Fuller, eds., Academic Press, New York, pp 215-273.

Green, R. H. 1979. Sampling Design and Statistical Methods for Environmental Biologists, John Wiley \& Sons, New York.

Hughes, R. G. 1986. "Theories and Models of Species Abundance," American Naturalist, Vol 128, pp 879-899.

Hurlbert, S. H. 1984. "Pseudoreplication and the Design of Ecological Field Experiments," Ecological Monographs, Vol 54, pp 187-211.

Isom, B. G., and Gooch, C. 1986. "Rationale and Sampling Design for Freshwater Mussels, Unionidae, in Streams, Large Rivers, Impoundments, and Lakes," Rationale for Sampling and Interpretation of Ecological Data in the Assessment of Freshwater Ecosystems, ASTM STP 894, B. G. Isom, ed., American Society for Testing and Materials, Philadelphia, PA, pp 46-59. 
Kovalak, W. P., Dennis, S. D., and Bates, J. M. 1986. "Sampling Effort Required to Find Rare Species of Freshwater Mussels," Rationale for Sampling and Interpretation of Ecological Data in the Assessment of Freshwater Ecosystems, ASTM STP 894, B. G. Isom, ed., American Society for Testing and Materials, Philadelphia, PA, pp 34-45.

McNaughton, S. J., and Wolf, L. L. 1973. General Ecology, Holt, Rinehart, and Winston, Inc., New York.

Miller, A. C., and Nelson, D. A. 1983. "An Instruction Report on Freshwater Mussels," Instruction Report EL-83-2, US Army Engineer Waterways Experiment Station, Vicksburg, MS.

Miller, A. C., and Payne, B. S. 1988. "The Need for Quantitative Sampling to Characterize Size Demography and Density of Freshwater Mussel Communities," Bulletin of the American Malacological Union, Inc., Vol 6, pp 49-54.

- "The Impacts of Commercial Navigation Traffic on Freshwater Mussels at the Zimmer Power Plant, Ohio River-Baseline Studies; Phase II," Technical Report (in preparation), US Army Engineer Waterways Experiment Station, Vicksburg, MS.

Miller, A. C., Payne, B. S., Hornbach, D. J., and Ragland, D. V. 1990. "An Investigation of the Physical Effects of Increased Commercial Navigation Traffic on Freshwater Mussels in the Upper Mississippi River: Phase I Studies," Technical Report EL-90-3, US Army Engineer Waterways Experiment Station, Vicksburg, MS.

Miller, A. C., Payne, B. S., and Siemsen, T. S. 1986. "Description of Habitat of the Endangered Mussel Plethobasus cooperianus," The Nautilus, Vol 100, pp 14-18.

Murry, H. D., and Leonard, A. B. 1962. "Handbook of Unionid Mussels in Kansas," Museum of Natural History, University of Kansas, Lawrence, KS.

Ortmann, A. E. 1925. "The Naiad-Fauna of the Tennessee River System Below Walden Gorge," American Midland Naturalist, Vol 9, pp 321-371.

Parmalee, P. W. 1967. "The Fresh-water Mussels of Illinois," Illinois State Museum Popular Science Series, Vol 8, pp 1-108.

Payne, B. S., and Miller, A. C. 1989. "Growth and Survival of Recent Recruits to a Population of Fusconaia ebena (Bivalvia: Unionidae) in the Lower Ohio River," American Midland Naturalist, Vol 121, pp 99-104. 
Rasmussen, J. L. 1983. "A Summary of Known Navigation Effects and a Priority List of Data Gaps for the Biological Effects of Navigation on the Upper Mississippi River," Prepared for the US Army Engineer District, Rock Island, by US Fish and Wildlife Service, Contract No. NCR-LO-83-C9, Rock Island, IL.

Shannon, C. E., and Weaver, W. 1949. The Mathematical Theory of Communication, University of Illinois Press, Urbana, IL.

Starrett, W. C. 1971. "A Survey of the Mussels (Unionidae) of the Illinois River: A Polluted Stream," Illinois Natural History Survey Bulletin, Vol 30, No. 5, pp 266-403.

US Fish and Wildlife Service. 1987. "Endangered and Threatened Wildlife and Plants," 50 CFR 17.11 \& 17.12, Office of Endangered Species, US Fish and Wildlife Service, Washington, DC.

Way, C. M., Miller, A. C., and Payne, B. S. 1989. "The Influence of Physical Factors on the Distribution and Abundance of Freshwater Mussels (Bivalvia: Unionidae) in the Lower Tennessee River," The Nautilus, Vol 103, pp 96-98.

Williams, J. C. 1969. "Mussel Fishery Investigations, Tennessee, Ohio and Green Rivers," Project Completion Report for Investigations Projects Conducted Under the Commercial Fisheries Research and Development Act of 1964, US Fish and Wildlife Service and Kentucky Department of Fish and Wildlife Resources.

Wright, T. D. 1982. "Potential Biological Impacts of Navigation Traffic," Miscellaneous Paper E-82-2, US Army Engineer Waterways Experiment Station, Vicksburg, MS. 



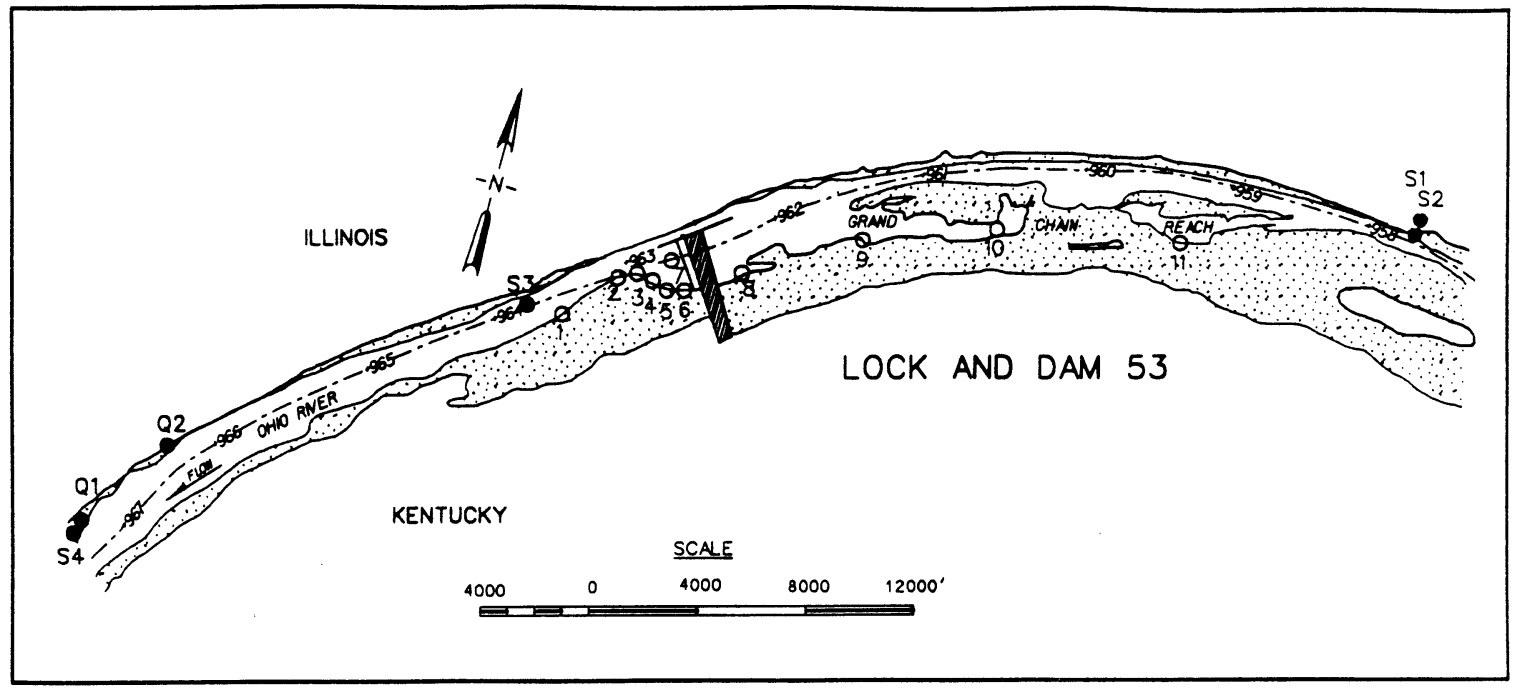

Figure 1. Sites surveyed for mussels in the lower Ohio River, September 1990. Q1 and Q2 were sampled using quantitative methods and S1-S4 were surveyed using qualitative methods. No mussels were found at Sites 1-11

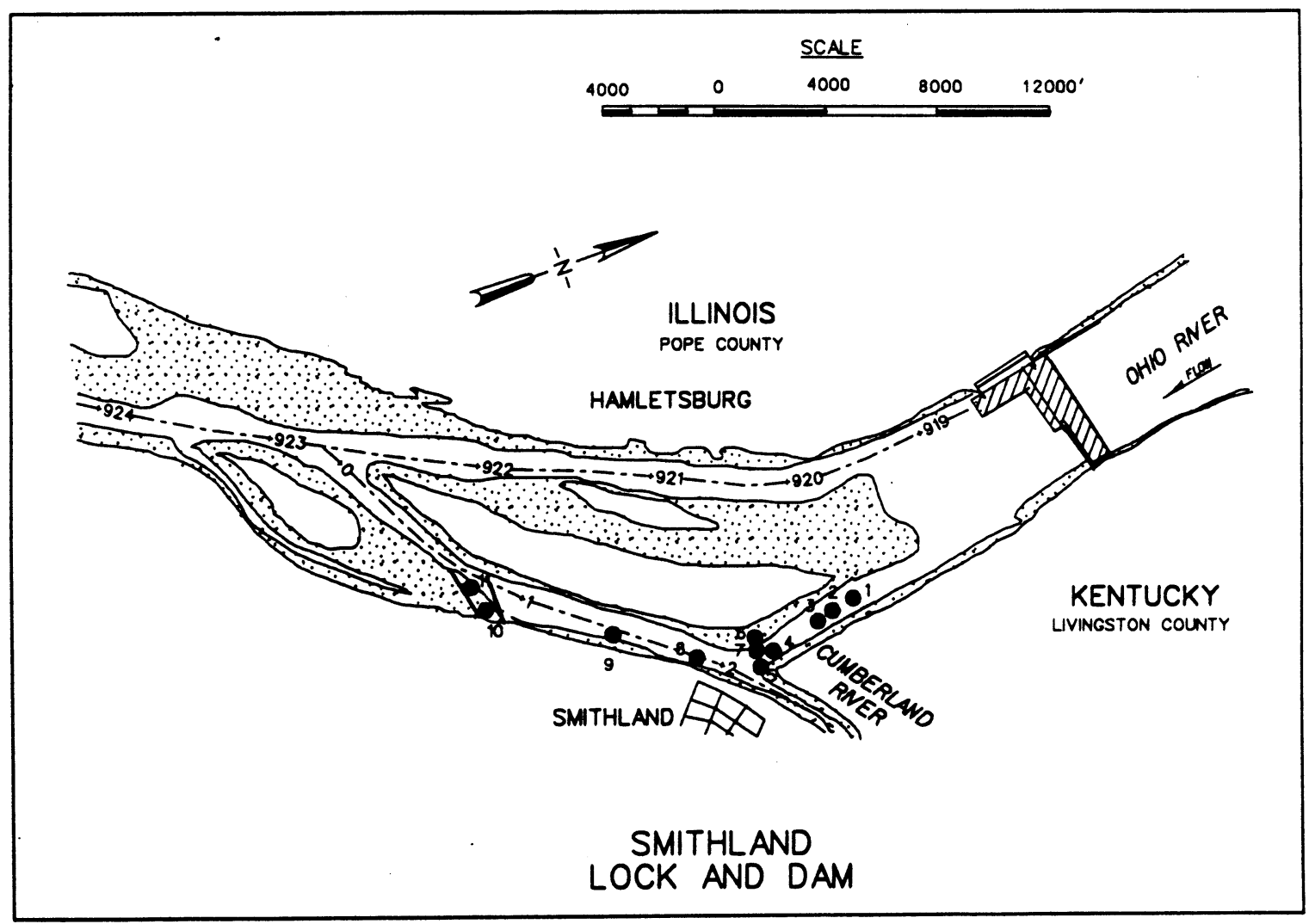

Figure 2. Sites surveyed for mussels in the lower Cumberland River, September 1990. Mussels were found at Sites 8 and 10

WES TR EL-91-9, July 1991 


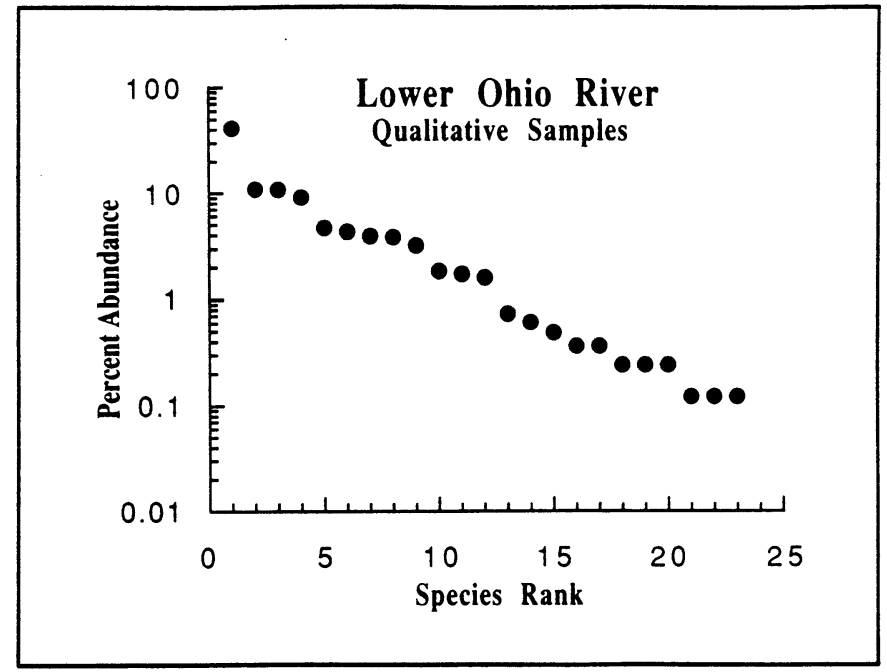

Figure 3. The relationship between percent abundance and species rank for mussels collected using qualitative methods in the lower Ohio River, September 1990

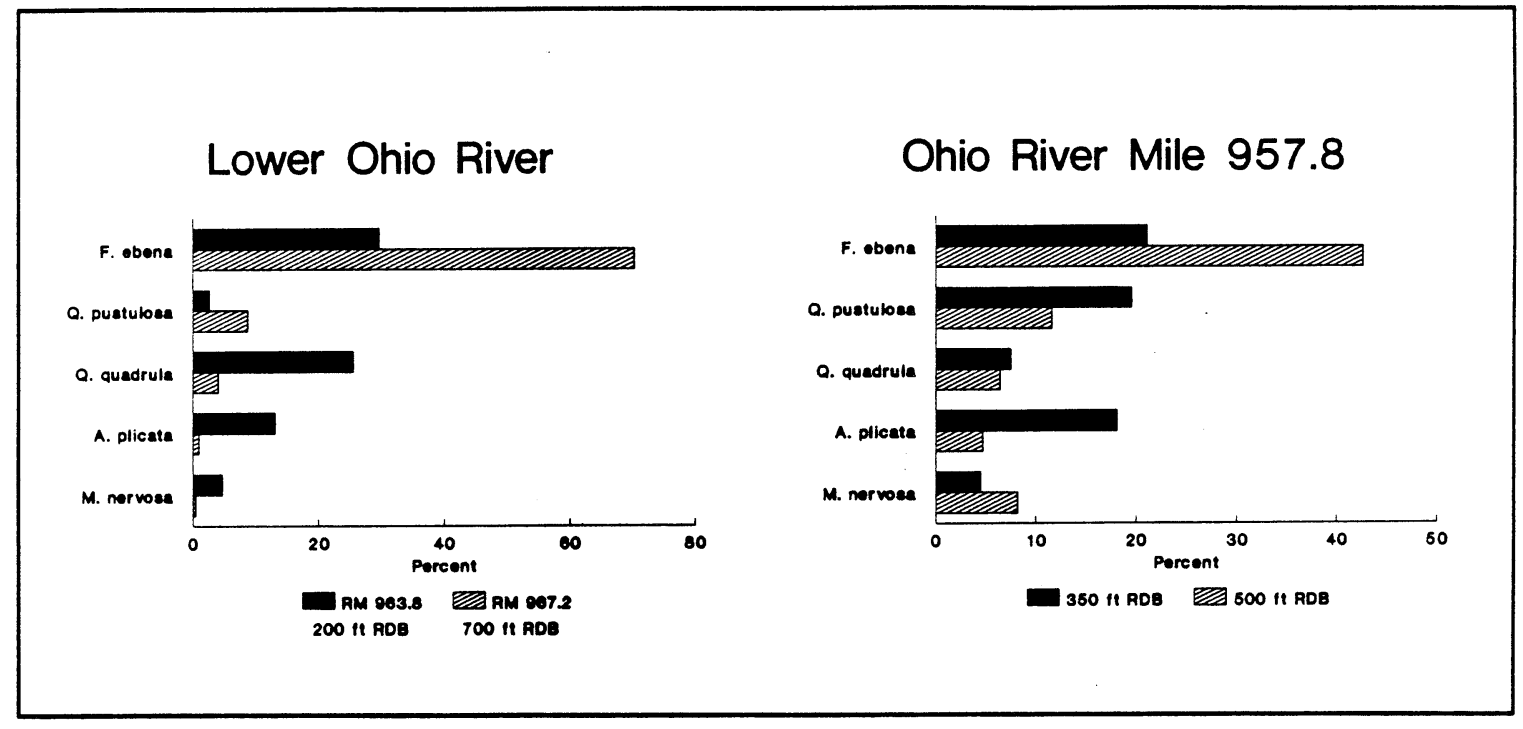

Figure 4. Results of qualitative freshwater mussel collections in the lower Ohio River, September 1990 


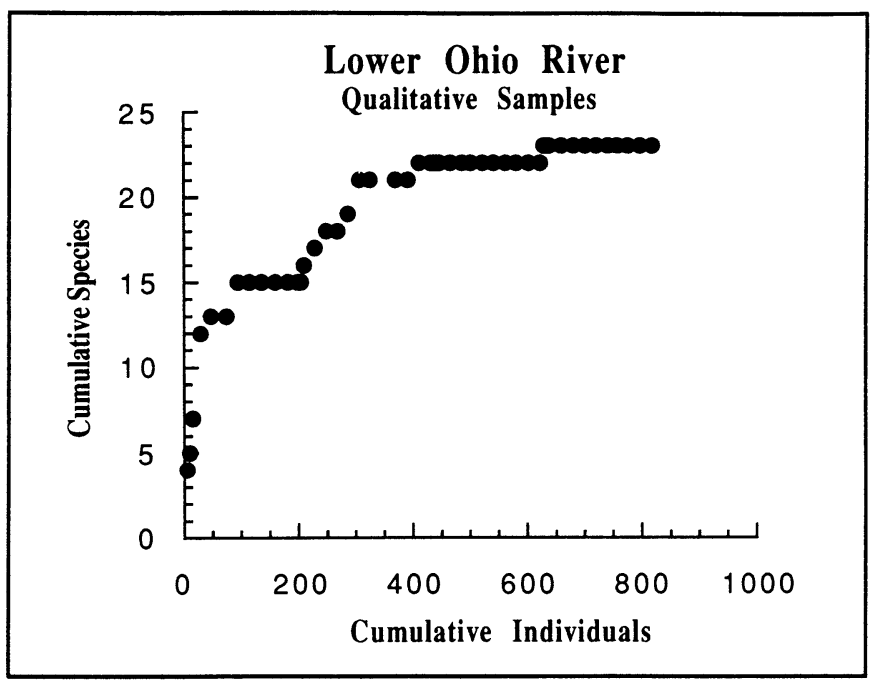

Figure 5. The relationship between cumulative species and cumulative individuals collected using qualitative methods in the lower Ohio River, September 1990

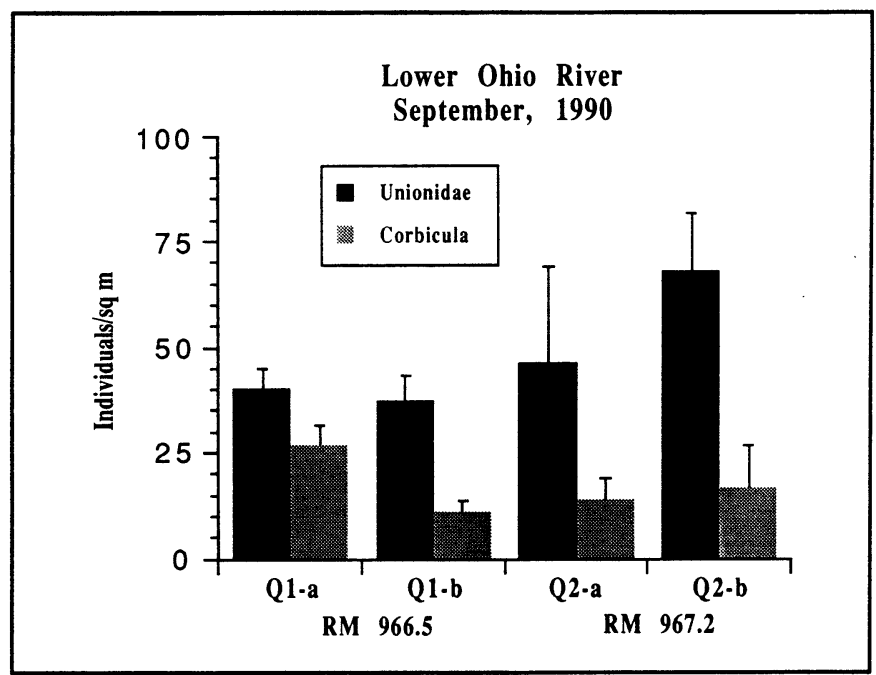

Figure 6. Total density (individuals/sq $\mathrm{m}$ ) of unionids and $C$. fluminea collected in the lower Ohio River, September 1990 


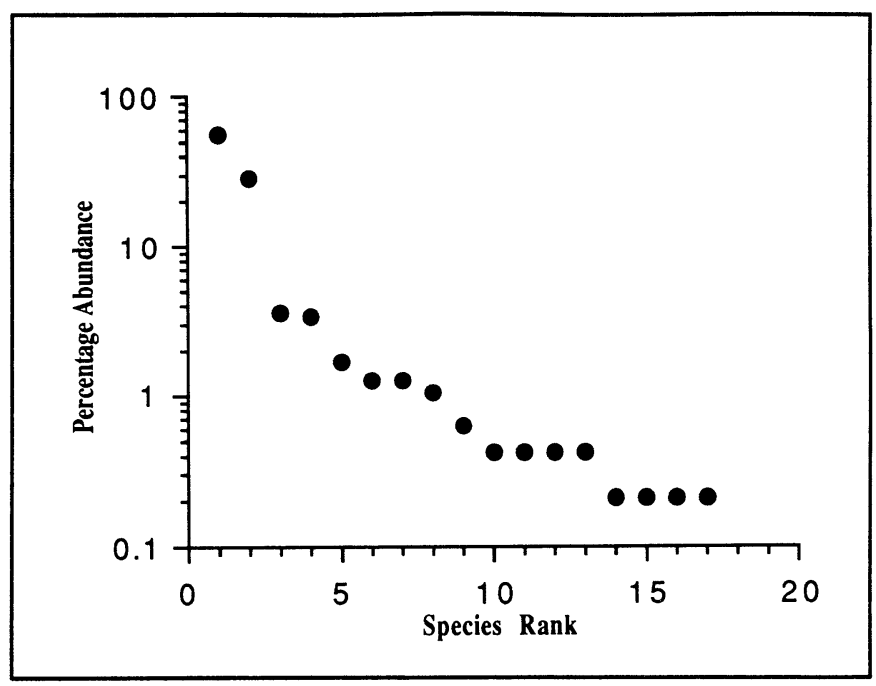

a. The relationship between percentage abundance and species rank

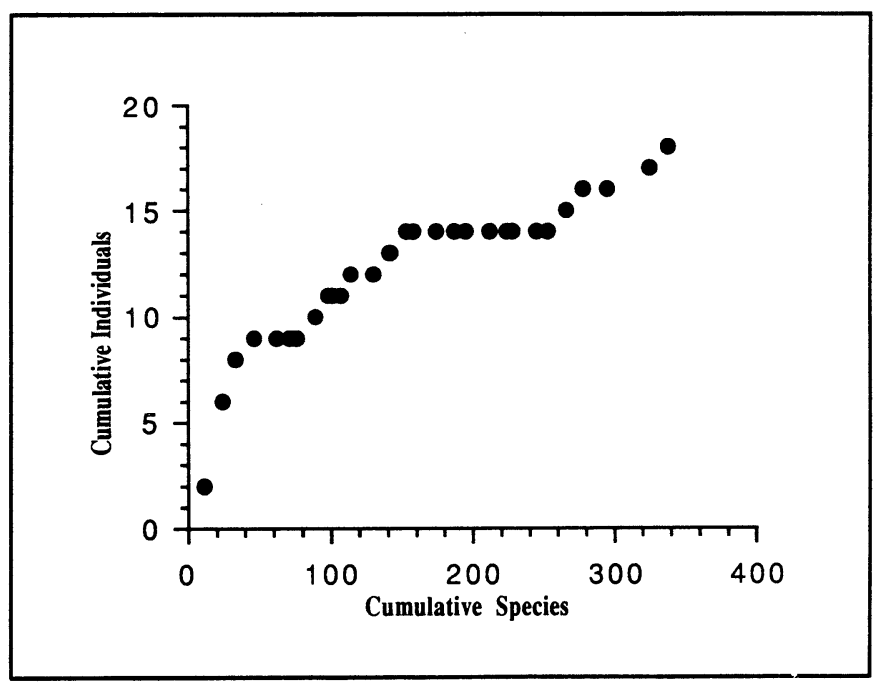

b. The relationship between cumulative individuals and cumulative species

Figure 7. Results of quantitative freshwater mussel collections in the lower Ohio River, September 1990 


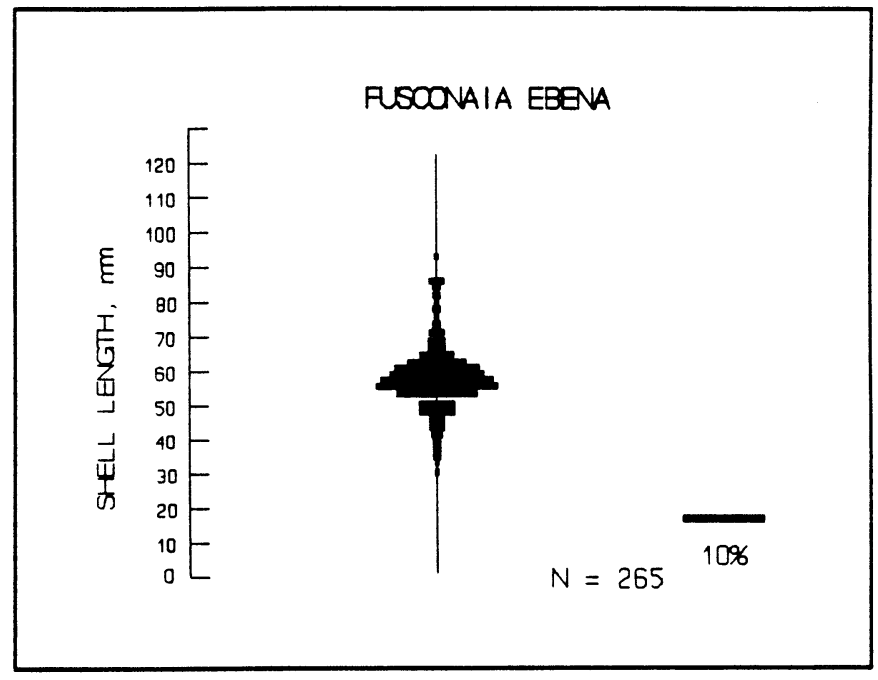

a. Length-frequency histogram

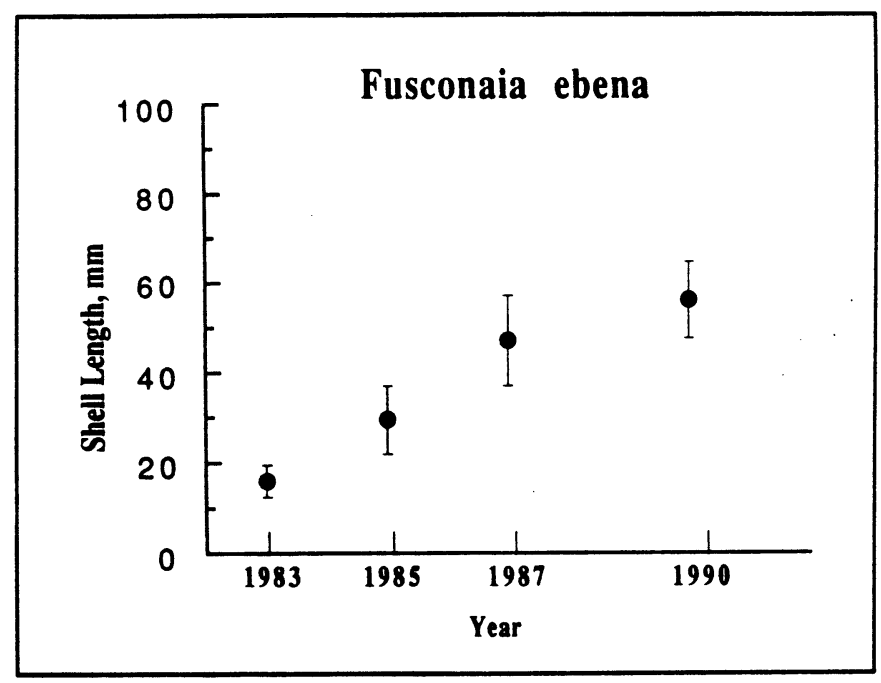

b. Mean and range shell length

Figure 8. Demographic analysis of $F$. ebena 


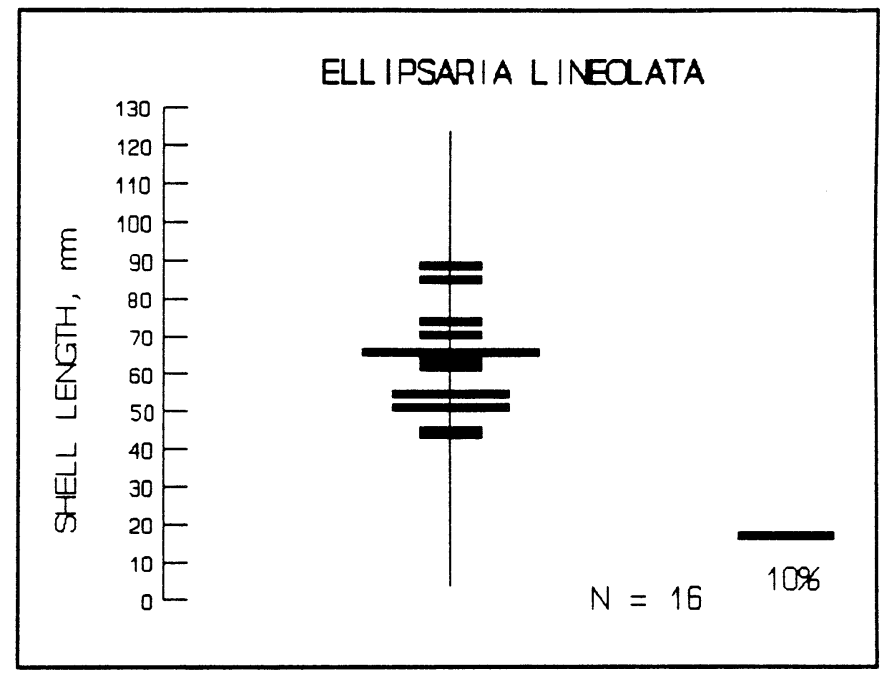

Figure 9. Length-frequency histogram for Ellipsaria lineolata

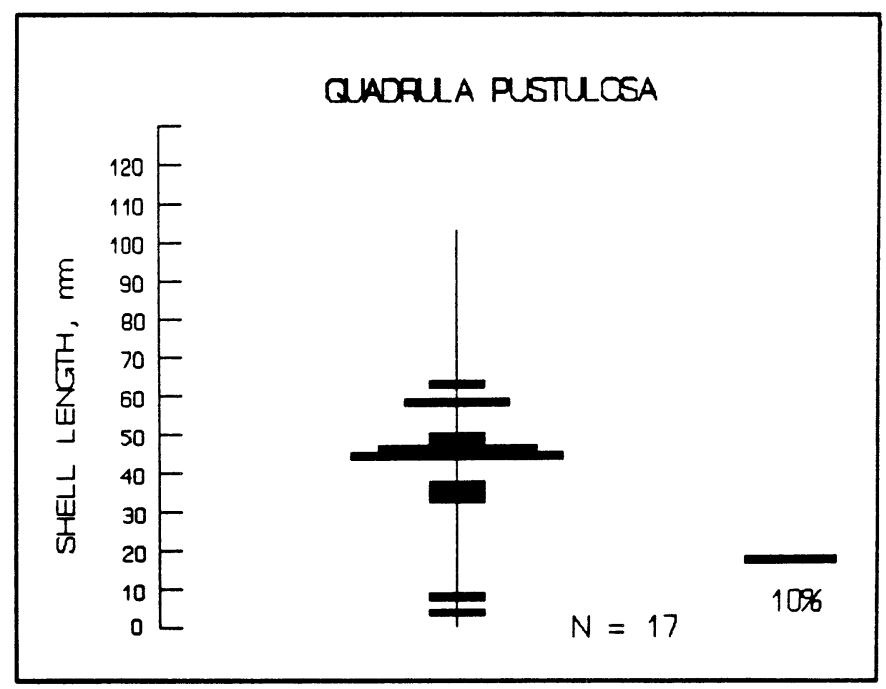

Figure 10. Length-frequency histogram for Quadrula pustulosa 


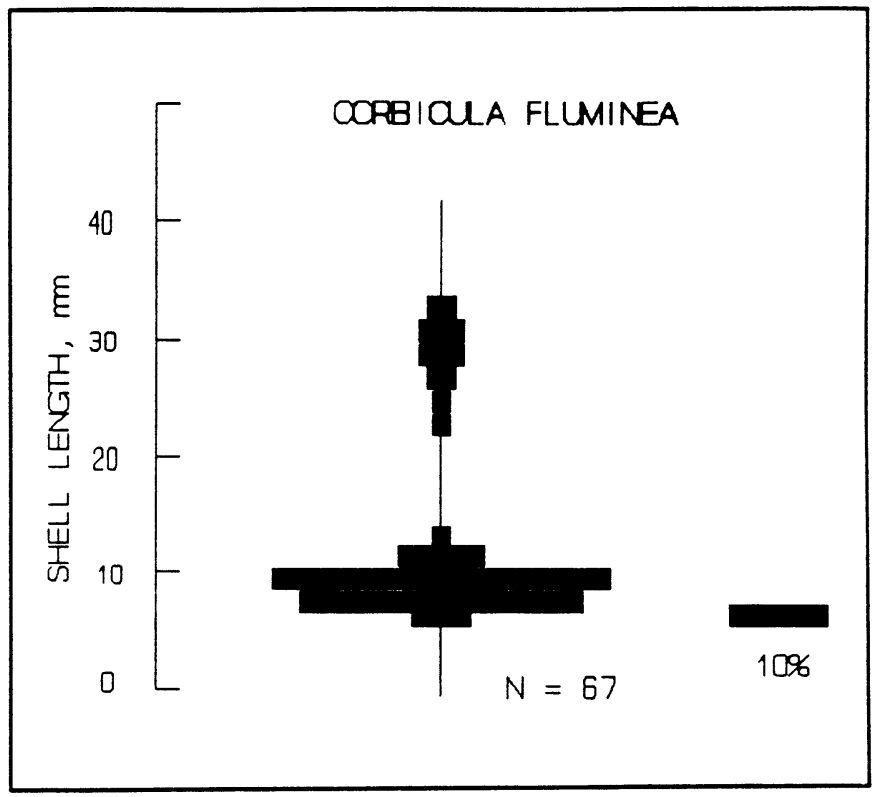

a. Farshore site, $700 \mathrm{ft}$ from RDB, RM 967.2

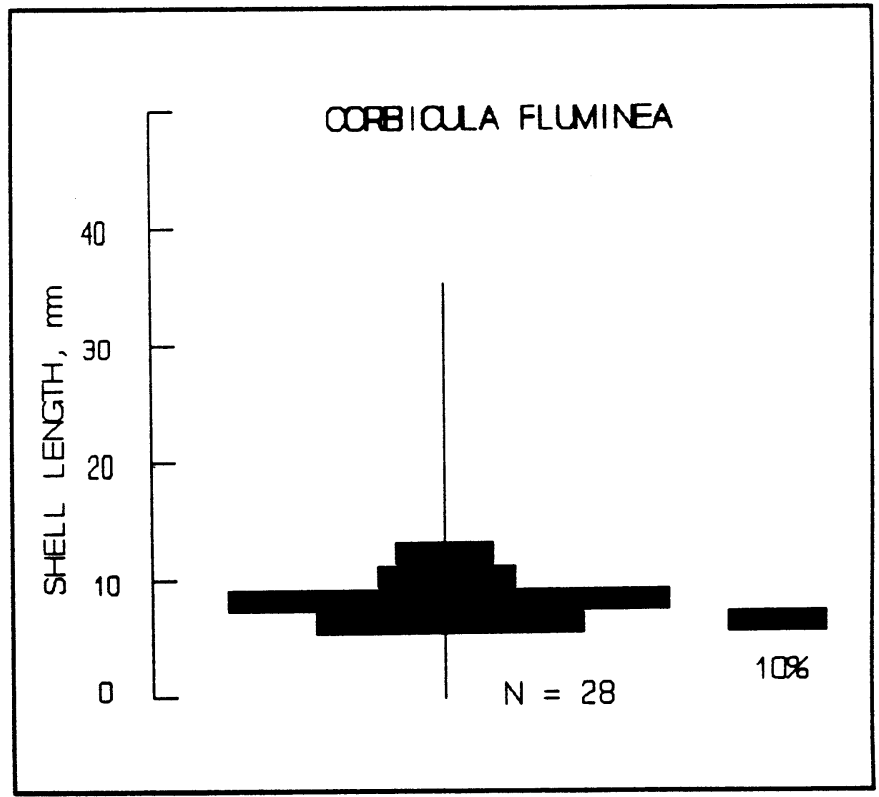

b. Nearshore site, $500 \mathrm{ft}$ from RDB, RM 967.2

Figure 11. Length-frequency histograms for Corbicula fluminea 


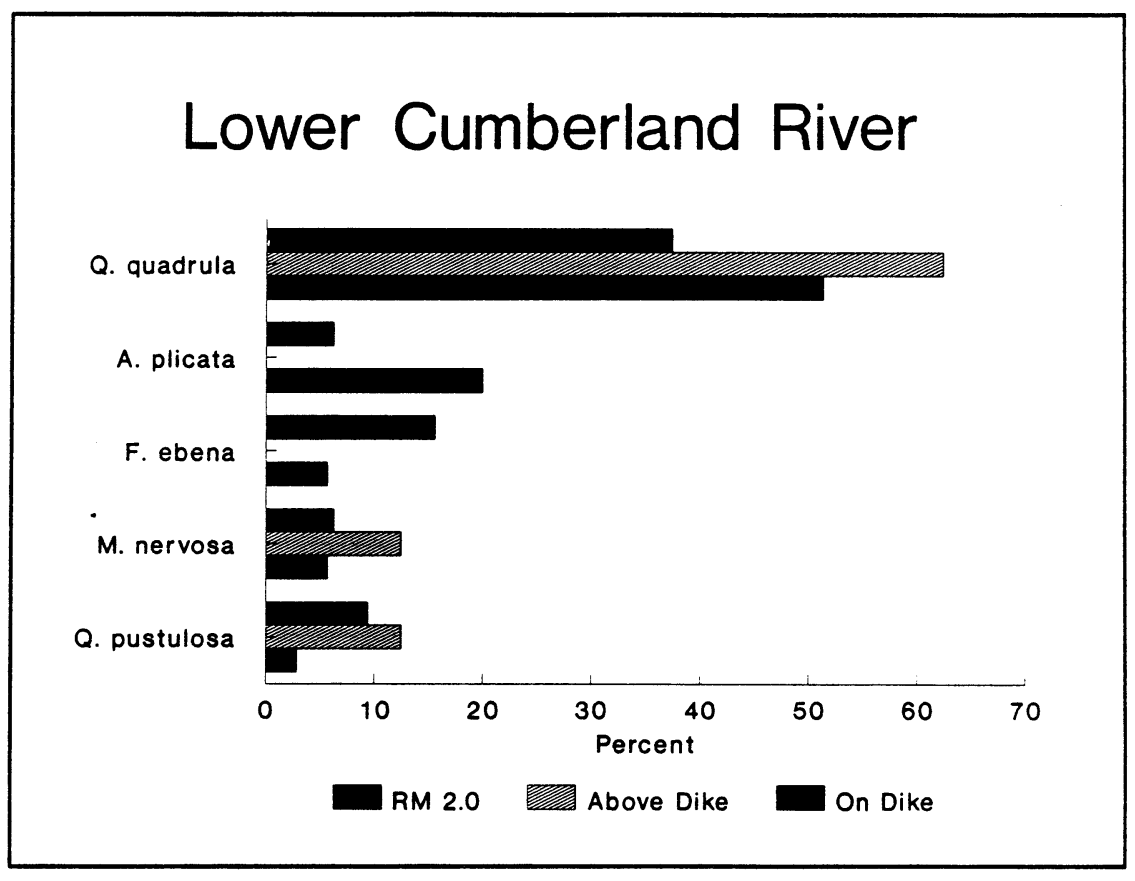

Figure 12. Relative abundance of five species of freshwater mussels at three sites in the lower Cumberland River, September 1990 


\begin{tabular}{|c|c|c|c|c|c|}
\hline Study Area & Site No. & RM & $\begin{array}{l}\text { Distance to } \\
\text { Shore }\end{array}$ & Water Depth & $\begin{array}{l}\text { No. of } \\
\text { Samples }\end{array}$ \\
\hline Lower Ohio River & $\begin{array}{l}Q 1 \\
Q 2 \\
Q 2 \\
\text { S1 } \\
\text { S2 } \\
\text { S3 } \\
\text { S4 }\end{array}$ & $\begin{array}{l}967.2 \\
966.5 \\
966.5 \\
957.8 \\
957.8 \\
963.8 \\
967.2\end{array}$ & $\begin{array}{l}500-700 \\
300 \\
230 \\
350 \\
500 \\
200 \\
700\end{array}$ & $\begin{array}{l}14 \\
15 \\
14 \\
15 \\
14 \\
14 \\
15\end{array}$ & $\begin{array}{r}20 \\
5 \\
5 \\
12 \\
12 \\
12 \\
12\end{array}$ \\
\hline $\begin{array}{l}\text { Lower Cumberland } \\
\text { River }\end{array}$ & $\begin{array}{c}8 \\
10^{1} \\
10^{2}\end{array}$ & $\begin{array}{l}2.0 \\
0.8 \\
0.8\end{array}$ & $\begin{array}{l}125 \\
400 \\
400\end{array}$ & $\begin{array}{l}12 \\
10 \\
5-10\end{array}$ & $\begin{array}{l}1 \\
1 \\
1\end{array}$ \\
\hline \multicolumn{6}{|c|}{$\begin{array}{l}\text { Notes: Q1-Q2: } 0.25 \text { sq m quantitative samples. } \\
\text { s1-s4: Qualitative samples. } \\
1 \text { Upriver of dike. } \\
2 \text { On dike. }\end{array}$} \\
\hline
\end{tabular}

WES TR EL-91-9, July 1991 


\begin{tabular}{|c|c|c|c|c|}
\hline Species & Total Mussels & Abundance & Total Sites & Frequency \\
\hline Fusconaia ebena (I. Lea 1831) & 335 & 0.4095 & 46 & 0.9583 \\
\hline Quadrula p. pustulosa (I. Lea 1831) & 88 & 0.1076 & 32 & 0.6667 \\
\hline Quadrula quadrula (Rafinesque 1820) & 87 & 0.1064 & 32 & 0.6667 \\
\hline Amblema p. plicata (Say 1817) & 74 & 0.0905 & 29 & 0.6042 \\
\hline Megalonaias nervosa (Rafinesque 1820) & 38 & 0.0465 & 21 & 0.4375 \\
\hline Ellipsaria lineolata (Rafinesque 1820) & 35 & 0.0428 & 22 & 0.4583 \\
\hline Obliquaria reflexa (Rafinesque 1820) & 32 & 0.0391 & 23 & 0.4792 \\
\hline Quadrula metanevra (Rafinesque 1820) & 31 & 0.0379 & 24 & 0.5000 \\
\hline Obovaria olivaria (Rafinesque 1820) & 26 & 0.0318 & 12 & 0.2500 \\
\hline Tritogonia verrucosa (Rafinesque 1820) & 15 & 0.0183 & 11 & 0.2292 \\
\hline Quadrula nodulata (Rafinesque 1820) & 14 & 0.0171 & 12 & 0.2500 \\
\hline Potamilus alatus (Say 1817) & 13 & 0.0159 & 11 & 0.2292 \\
\hline Elliptio crassidens (Lamarck 1819) & 6 & 0.0073 & 7 & 0.1458 \\
\hline Pleurobema cordatum (Rafinesque 1820) & 5 & 0.0061 & 5 & 0.1042 \\
\hline Cyclonaias tuberculata (Rafinesque 1820) & 4 & 0.0049 & 4 & 0.0833 \\
\hline Lampsilis ventricosa (I. Lea 1858) & 3 & 0.0037 & 2 & 0.0417 \\
\hline Truncilla truncata (Rafinesque 1820) & 3 & 0.0037 & 3 & 0.0625 \\
\hline Leptodea fragilis (Rafinesque 1820) & 2 & 0.0024 & 2 & 0.0417 \\
\hline Lasmigona c. complanata (Barnes 1823) & 2 & 0.0024 & 2 & 0.0417 \\
\hline Plethobasus cooperianus (I. Lea 1834) & 2 & 0.0024 & 2 & 0.0417 \\
\hline Actinonaias ligamentina (Lamarck 1819) & 1 & 0.0012 & 1 & 0.0208 \\
\hline Ligumia recta (Lamarck 1819) & 1 & 0.0012 & 1 & 0.0208 \\
\hline Plethobasus cyphyus (Rafinesque 1820) & 1 & 0.0012 & 1 & 0.0208 \\
\hline \multicolumn{5}{|l|}{$\begin{array}{lr}\text { Total samples: } & 48 \\
\text { Total mussels: } & 818 \\
\text { Total species: } & 23\end{array}$} \\
\hline
\end{tabular}




\begin{tabular}{|c|c|c|c|c|c|c|c|c|}
\hline $\begin{array}{l}\text { Table } 3 \\
\text { Relative Species } \\
\text { at Each of Four }\end{array}$ & $\begin{array}{l}\text { Abund } \\
\text { Sites in }\end{array}$ & $\begin{array}{l}\text { e for Fres } \\
\text { Lower OI }\end{array}$ & $\begin{array}{l}\text { ter Mus } \\
\text { iver, } \mathbf{S}\end{array}$ & $\begin{array}{l}\text { Collecte } \\
\text { nber } 199\end{array}$ & $\mathbf{g} Q u$ & ve Techn & & \\
\hline \multirow[b]{2}{*}{ Specles } & \multicolumn{2}{|c|}{$\begin{array}{c}\text { RM } 957.8 \\
350 \text { ft RDB }\end{array}$} & \multicolumn{2}{|c|}{$\begin{array}{c}\text { RM } 957.8 \\
500 \mathrm{ft} \text { RDB }\end{array}$} & \multicolumn{2}{|c|}{$\begin{array}{c}\text { RM } 963.8 \\
200 \mathrm{ft} \text { RDB }\end{array}$} & \multicolumn{2}{|c|}{$\begin{array}{c}\text { RM } 967.2 \\
700 \text { ft RDB }\end{array}$} \\
\hline & $\mathbf{N}$ & Abundance & $N$ & Abundance & N & Abundance & $\mathbf{N}$ & Abundance \\
\hline F. ebena & 42 & 0.2111 & 99 & 0.4267 & 57 & 0.2969 & 137 & 0.7026 \\
\hline Q. pustulosa & 39 & 0.1960 & 27 & 0.1164 & 5 & 0.0260 & 17 & 0.0872 \\
\hline Q. quadrula & 15 & 0.0754 & 15 & \begin{tabular}{|l|}
0.0647 \\
\end{tabular} & 49 & 0.2552 & 8 & 0.0410 \\
\hline A. plicata & 36 & 0.1809 & 11 & 0.0474 & 25 & 0.1302 & 2 & 0.0103 \\
\hline M. gigantea & 9 & 0.0452 & 19 & 0.0819 & 9 & 0.0469 & 1 & 0.0051 \\
\hline E. lineolata & 6 & 0.0302 & 14 & \begin{tabular}{|l|}
0.0603 \\
\end{tabular} & 0 & 0.0000 & 15 & 0.0769 \\
\hline O. refiexa & 12 & 0.0603 & 10 & 0.0431 & 8 & 0.0417 & 2 & 0.0103 \\
\hline Q. metanevra & 13 & 0.0653 & 11 & \begin{tabular}{|l|}
0.0474 \\
\end{tabular} & 2 & 0.0104 & 5 & 0.0256 \\
\hline O. olivaria & 2 & 0.0101 & 6 & \begin{tabular}{|l|}
0.0259 \\
\end{tabular} & 18 & 0.0938 & 0 & 0.0000 \\
\hline T. verrucosa & 8 & 0.0402 & 2 & 0.0086 & 5 & 0.0260 & 0 & 0.0000 \\
\hline Q. nodulata & 4 & 0.0201 & 2 & 0.0086 & 8 & 0.0417 & 0 & 0.0000 \\
\hline P. alatus & 5 & 0.0251 & 1 & 0.0043 & 5 & 0.0260 & 2 & 0.0103 \\
\hline E. crassidens & 3 & 0.0151 & 0 & 0.0000 & 0 & 0.0000 & 3 & 0.0154 \\
\hline P. cordatum & 1 & 0.0050 & 3 & 0.0129 & 0 & 0.0000 & 1 & 0.0051 \\
\hline C. tuberculata & 2 & 0.0101 & 2 & 0.0086 & 0 & 0.0000 & 0 & 0.0000 \\
\hline L. ventricosa & 0 & 0.0000 & 3 & 0.0129 & 0 & 0.0000 & 0 & 0.0000 \\
\hline T. truncata & 0 & 0.0000 & 2 & 0.0086 & 1 & 0.0052 & 0 & 0.0000 \\
\hline L. fragilis & 0 & 0.0000 & 2 & 0.0086 & 0 & 0.0000 & 0 & 0.0000 \\
\hline L. complanata & 2 & 0.0101 & 0 & 0.0000 & 0 & 0.0000 & 0 & 0.0000 \\
\hline P. cooperianus & 0 & 0.0000 & 1 & 0.0043 & 0 & 0.0000 & 1 & 0.0051 \\
\hline A. ligamentina & 0 & 0.0000 & 1 & 0.0043 & 0 & 0.0000 & 0 & 0.0000 \\
\hline L. recta & 0 & 0.0000 & 0 & 0.0000 & 0 & 0.0000 & 1 & 0.0051 \\
\hline P. cyphyus & 0 & 0.0000 & 1 & 0.0043 & 0 & 0.0000 & 0 & 0.0000 \\
\hline $\begin{array}{l}\text { Total species } \\
\text { Total individuals } \\
\text { Species diversity (H') } \\
\text { Evenness (J) }\end{array}$ & $\begin{array}{c}16 \\
199 \\
2.27 \\
0.82 \\
\end{array}$ & & $\begin{array}{r}20 \\
232 \\
2.09 \\
0.67 \\
\end{array}$ & & $\begin{array}{r}12 \\
192 \\
1.97 \\
0.79 \\
\end{array}$ & & $\begin{array}{r}13 \\
195 \\
1.19 \\
0.45 \\
\end{array}$ & \\
\hline
\end{tabular}




\begin{tabular}{|c|c|c|c|c|c|c|c|c|}
\hline \multirow[b]{2}{*}{ Specles } & \multicolumn{2}{|c|}{$\begin{array}{c}\text { RM } 957.8 \\
350 \text { fi RDB }\end{array}$} & \multicolumn{2}{|c|}{$\begin{array}{c}\text { RM } 957.8 \\
500 \text { f RDB }\end{array}$} & \multicolumn{2}{|r|}{$\begin{array}{c}\text { RM } 963.8 \\
200 \mathrm{ft} \text { RDB }\end{array}$} & \multicolumn{2}{|c|}{$\begin{array}{c}\text { RM } 967.2 \\
700 \mathrm{ft} \text { RDB }\end{array}$} \\
\hline & $\mathbf{N}$ & Abundance & N & Frequency & $N$ & Frequency & $N$ & Frequency \\
\hline F. ebena & 12 & 1.0000 & 12 & 1.0000 & 10 & 0.8333 & 12 & 1.0000 \\
\hline A. plicata & 11 & 0.9167 & 7 & 0.5833 & 9 & 0.7500 & 2 & 0.1667 \\
\hline M. gigantea & 7 & 0.5833 & 8 & 0.6667 & 5 & 0.4167 & 1 & 0.0833 \\
\hline E. lineolata & 5 & 0.4167 & 8 & 0.6667 & 0 & 0.0000 & 9 & 0.7500 \\
\hline O. refiexa & 7 & 0.5833 & 8 & 0.6667 & 6 & 0.5000 & 2 & 0.1667 \\
\hline Q. metanevra & 9 & 0.7500 & 9 & 0.7500 & 1 & 0.0833 & 5 & 0.4167 \\
\hline O. olivaria & 1 & 0.0833 & 3 & 0.2500 & 8 & 0.6667 & 0 & 0.0000 \\
\hline P. cordatum & 1 & 0.0833 & 3 & 0.2500 & 0 & 0.0000 & 1 & 0.0833 \\
\hline C. tuberculata & 2 & 0.1667 & 2 & 0.1667 & 0 & 0.0000 & 0 & 0.0000 \\
\hline L. ventricosa & 0 & 0.0000 & 2 & 0.1667 & 0 & 0.0000 & 0 & 0.0000 \\
\hline$T$. truncata & 0 & 0.0000 & 2 & 0.1667 & 1 & 0.0833 & 0 & 0.0000 \\
\hline L. fragilis & 0 & 0.0000 & 2 & 0.1667 & 0 & 0.0000 & 0 & 0.0000 \\
\hline L. complanata & 2 & 0.1667 & 0 & 0.0000 & 0 & 0.0000 & 0 & 0.0000 \\
\hline P. cooperianus & 0 & 0.0000 & 1 & 0.0833 & 0 & 0.0000 & 1 & 0.0833 \\
\hline A. ligamentina & 0 & 0.0000 & 1 & 0.0833 & 0 & 0.0000 & 0 & 0.0000 \\
\hline L. recta & 0 & 0.0000 & 0 & 0.0000 & 0 & 0.0000 & 1 & 0.0833 \\
\hline P. cyphyus & 0 & 0.0000 & 1 & 0.0833 & 0 & 0.0000 & 0 & 0.0000 \\
\hline Total samples & 12 & & 12 & & 12 & & 12 & \\
\hline
\end{tabular}




\section{Table 5 \\ Relative Species Abundance and Summary Statistics for Quantitative Samples Collected in the Lower Ohio River, September 1990}

\begin{tabular}{|c|c|c|c|c|}
\hline \multirow[b]{2}{*}{ Species } & \multicolumn{2}{|c|}{ RM 966.5} & \multicolumn{2}{|c|}{ RM 967.2} \\
\hline & Q1-a & $\mathbf{a 1 - b}$ & Q2-a & Q2-b \\
\hline F. ebena & 0.4821 & 0.05820 & 0.6282 & 0.6038 \\
\hline C. fluminea & 0.3988 & 0.2295 & 0.2564 & 0.1981 \\
\hline Q. pustulosa & 0.0119 & 0.0492 & 0.0385 & 0.0566 \\
\hline E. lineolata & 0.0357 & 0.0574 & 0.0128 & 0.0189 \\
\hline A. plicata & 0.0000 & 0.0082 & 0.0128 & 0.0377 \\
\hline Q. metanevra & 0.0060 & 0.0410 & 0.0000 & 0.0000 \\
\hline O. reflexa & 0.0179 & 0.0082 & 0.0128 & 0.0283 \\
\hline T. truncata & 0.0060 & 0.0082 & 0.0000 & 0.0000 \\
\hline Q. quadrula & 0.0119 & 0.0000 & 0.0128 & 0.0189 \\
\hline F. flava & 0.0000 & 0.0000 & 0.0000 & 0.0000 \\
\hline Q. nodulata & 0.0000 & 0.0000 & 0.0000 & 0.0000 \\
\hline P. cordatum & 0.0060 & 0.0000 & 0.0128 & 0.0000 \\
\hline P. alatus & 0.0000 & 0.0164 & 0.0128 & 0.0000 \\
\hline E. crassidens & 0.0000 & 0.0000 & 0.0000 & 0.0094 \\
\hline M. nervosa & 0.0000 & 0.0000 & 0.0000 & 0.0189 \\
\hline P. cyphyus & 0.0000 & 0.0000 & 0.0000 & 0.0000 \\
\hline P. cooperianus & 0.0119 & 0.0000 & 0.0000 & 0.0000 \\
\hline C. tuberculata & 0.0000 & 0.0000 & 0.0000 & 0.0000 \\
\hline S. undulatus & 0.0000 & 0.0000 & 0.0000 & 0.0000 \\
\hline L. teres & 0.0060 & 0.0000 & 0.0000 & 0.0000 \\
\hline L. fragilis & 0.0060 & 0.0000 & 0.0000 & 0.0000 \\
\hline E. dilatata & 0.0000 & 0.0000 & 0.0000 & 0.0094 \\
\hline A. ligamentina & 0.0000 & 0.0000 & 0.0000 & 0.0000 \\
\hline $\begin{array}{l}\text { Total bivalves } \\
\text { Total species } \\
\text { Unionid density } \\
\text { (No./sq m) } \\
\text { C. fluminea density } \\
\text { (No./sq m) } \\
\text { Total samples }\end{array}$ & $\begin{array}{c}168 \\
12 \\
40.4 \\
26.8 \\
10\end{array}$ & $\begin{array}{c}122 \\
9 \\
37.6 \\
11.2 \\
10\end{array}$ & $\begin{array}{c}78 \\
9 \\
46.4 \\
16.0 \\
5\end{array}$ & $\begin{array}{c}106 \\
10 \\
68.0 \\
16.8 \\
5\end{array}$ \\
\hline
\end{tabular}

WES TR EL-91-๑, July 1991 


\begin{tabular}{|c|c|c|c|c|c|c|}
\hline \multicolumn{7}{|c|}{$\begin{array}{l}\text { Table } 6 \\
\text { Relative Abundance of Freshwater Mussels Collected in the Lower Cumberland River, } 23 \text { September } 1990\end{array}$} \\
\hline Species & \multicolumn{2}{|c|}{ Site 8} & \multicolumn{2}{|c|}{ Site 10, Upriver of Dike } & \multicolumn{2}{|c|}{ Site 10, On Dike } \\
\hline Q. quadrula & 12 & 0.3871 & 5 & 0.6250 & 18 & 0.5143 \\
\hline A. plicata & 1 & 0.0323 & 0 & 0.0000 & 7 & 0.2000 \\
\hline M. nervosa & 2 & 0.0645 & 1 & 0.1250 & 2 & 0.0571 \\
\hline Q. nodulata & 1 & 0.0323 & 1 & 0.1250 & 2 & 0.0571 \\
\hline F. flava & 1 & 0.0323 & 0 & 0.0000 & 2 & 0.0571 \\
\hline Q. metanevra & 2 & 0.0645 & 0 & 0.0000 & 0 & 0.0000 \\
\hline O. reflexa & 1 & 0.0323 & 0 & 0.0000 & 1 & 0.0286 \\
\hline $\begin{array}{l}\text { Total mussels } \\
\text { Total species }\end{array}$ & $\begin{array}{l}31 \\
12\end{array}$ & & $\begin{array}{l}8 \\
4\end{array}$ & & $\begin{array}{r}35 \\
8\end{array}$ & \\
\hline
\end{tabular}




\section{Appendix A Freshwater Mussels of the Lower Ohio River}

The following is a list of freshwater mussels (and $C$. fluminea) of the lower Ohio River collected in September 1990. Photographs of all species are provided on pages A2-A9. Species marked with an asterisk $\left(^{*}\right)$ were not collected alive using quantitative or qualitative methods. The orangefooted pimpleback (Plethobasus cooperianus) was photographed alive. Photographs were taken by Dr. Bill Pearson, Water Resources Laboratory, University of Louisville.

Actinonaias ligamentina Amblema p. plicata Corbicula fluminea Cyclonaias tuberculata Ellipsaria lineolata Elliptio crassidens

*Elliptio dilatata

Fusconaia ebena

* Fusconaia flava

Lampsilis ovata

* Lampsilis teres

Lasmigona c. complanata

Leptodea fragilis

Ligumia recta

Megalonaias nervosa

(=gigantea)
Obliquaria reflexa Obovaria olivaria Plethobasus cooperianus Plethobasus cyphus Pleurobema cordatum Potamilus alatus *Quadrula cylindrica cylindrica Quadrula metanevra Quadrula nodulata Quadrula p. pustulosa Quadrula quadrula Tritogonia verrucosa Truncilla truncata 


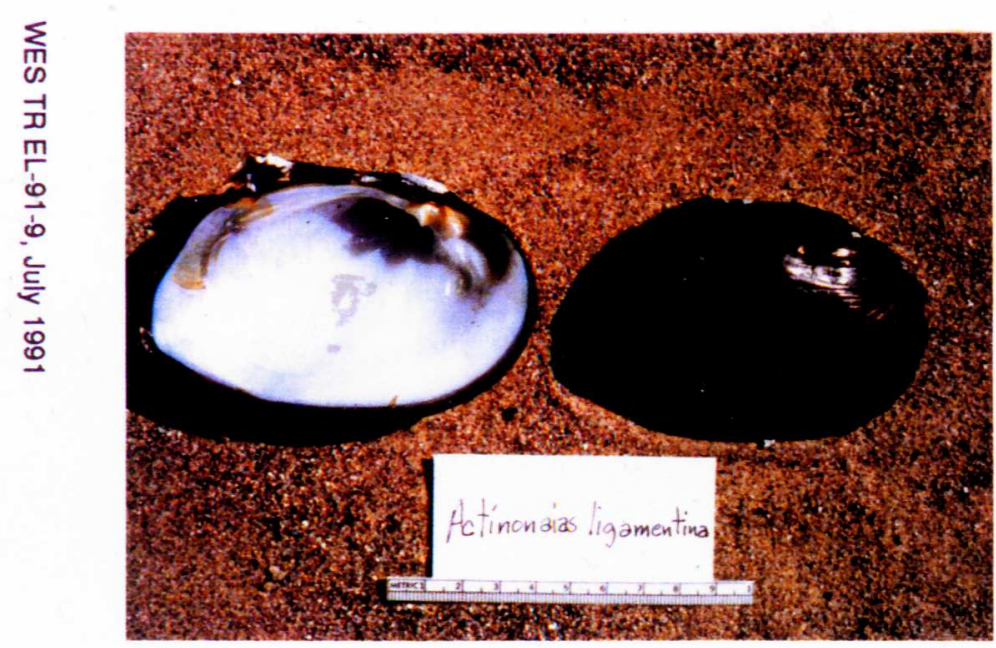

Figure A1

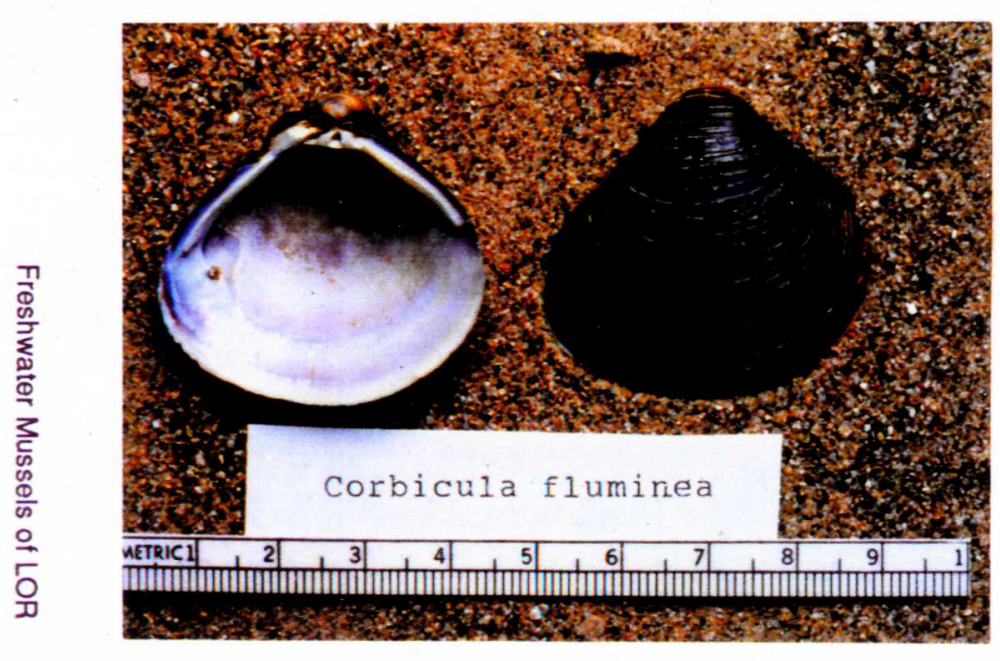

D

Figure $A 3$

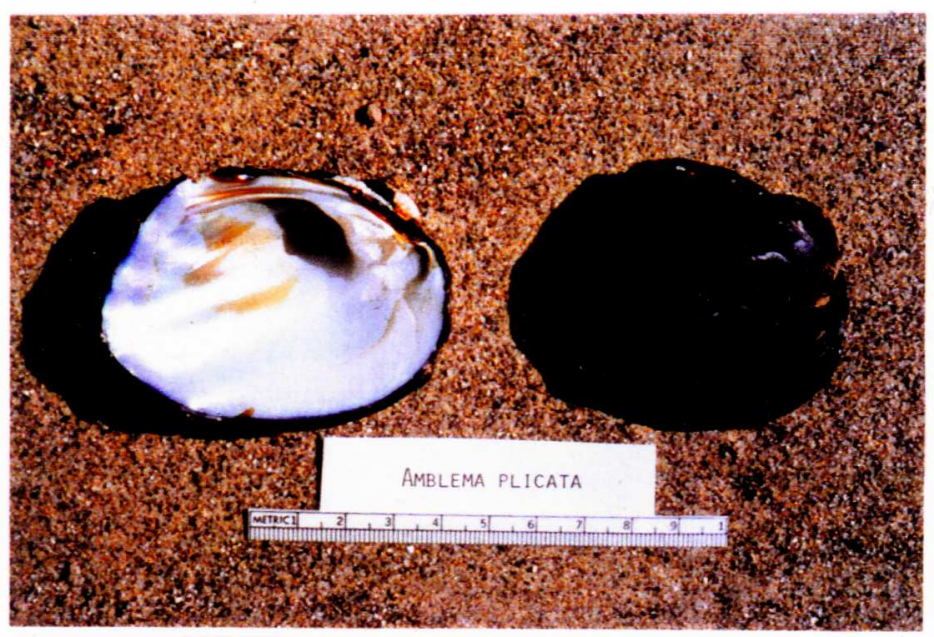

Figure A2

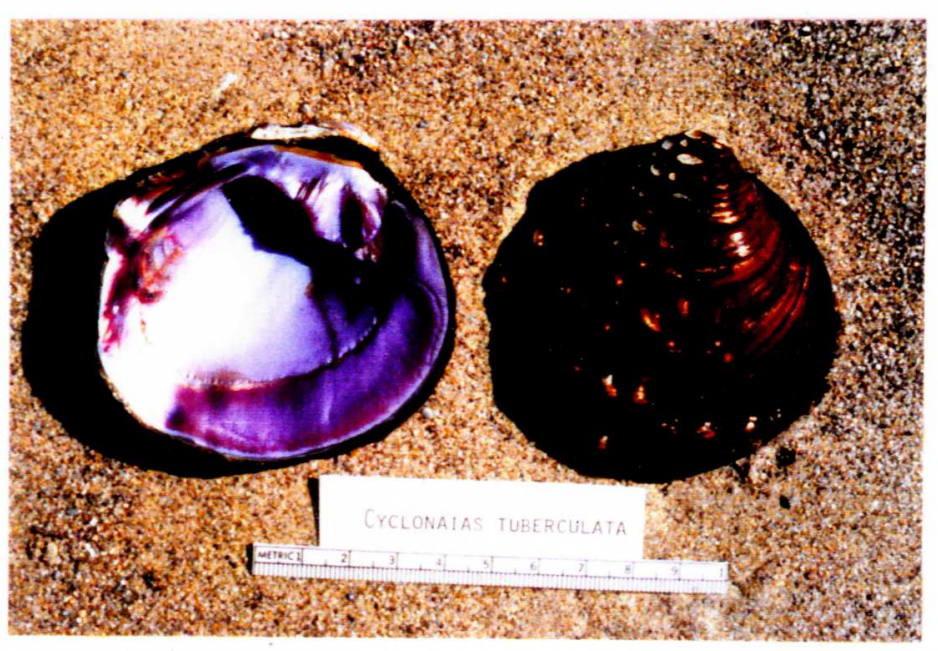

Figure A4 


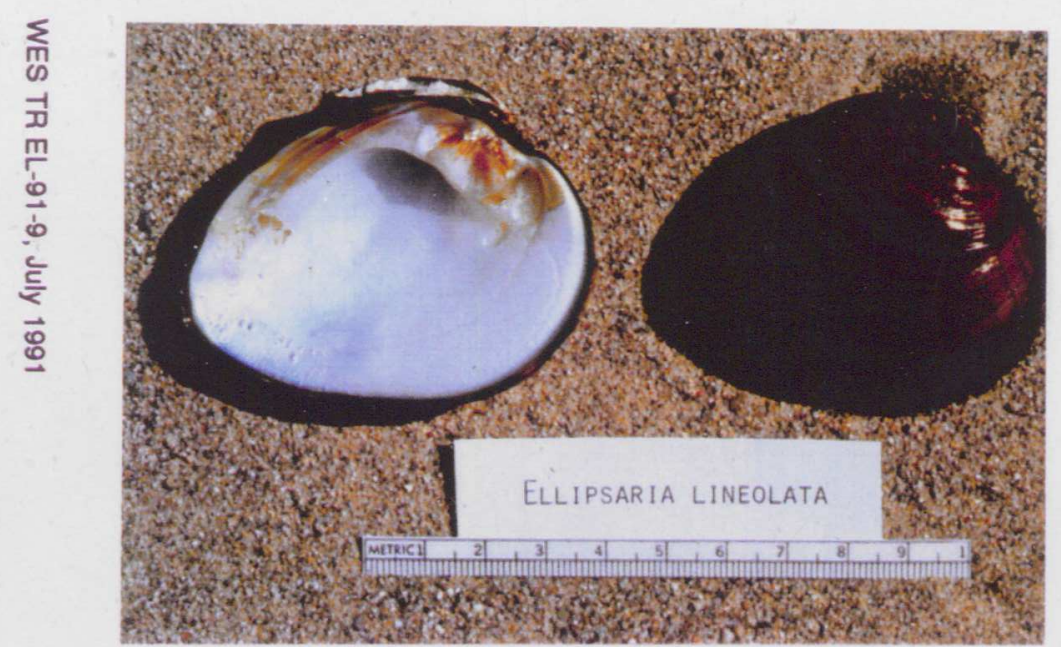

Figure A5

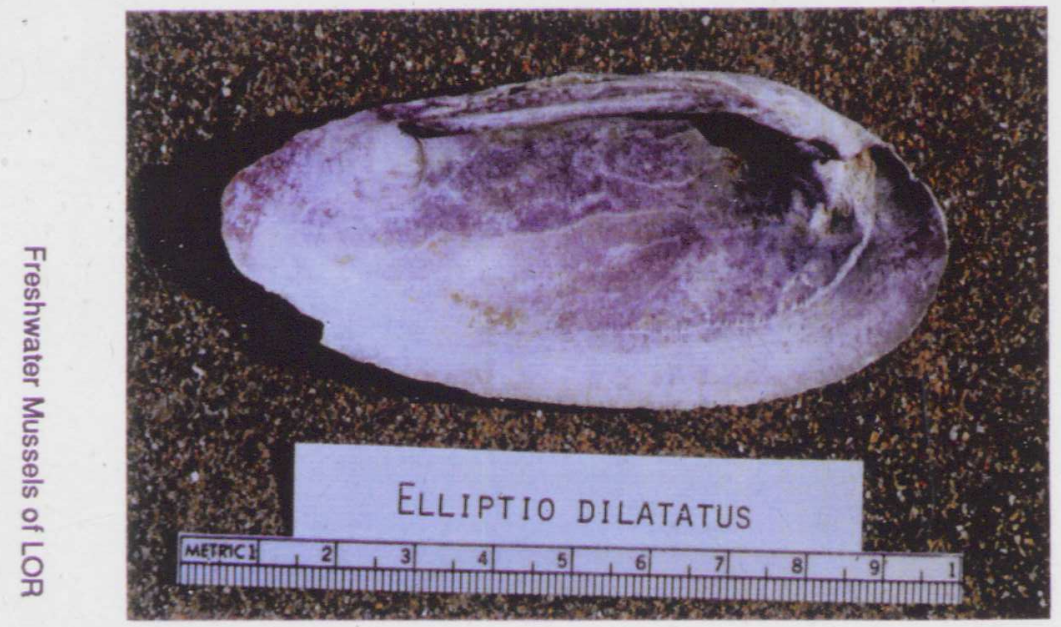

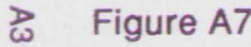

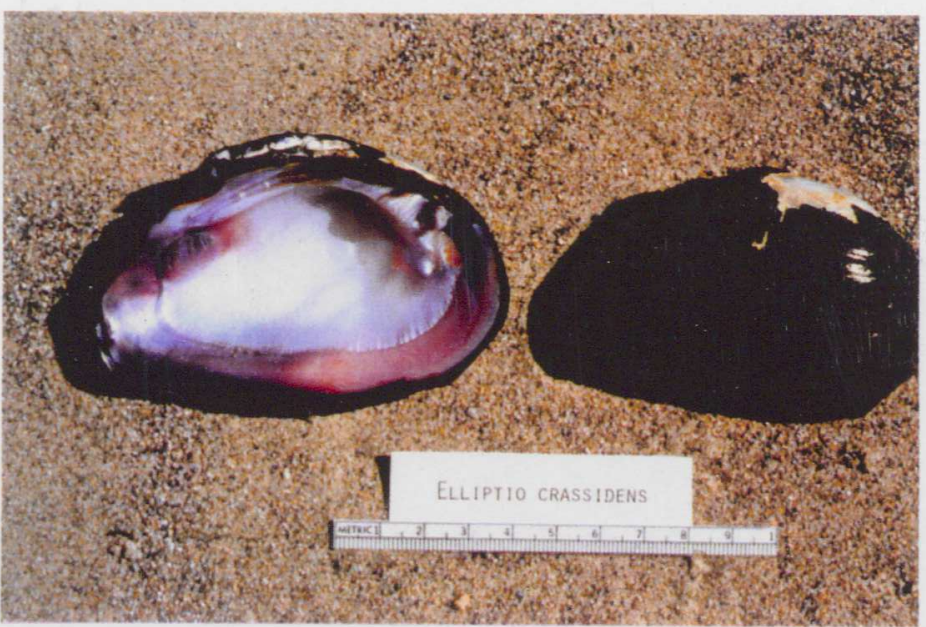

Figure A6

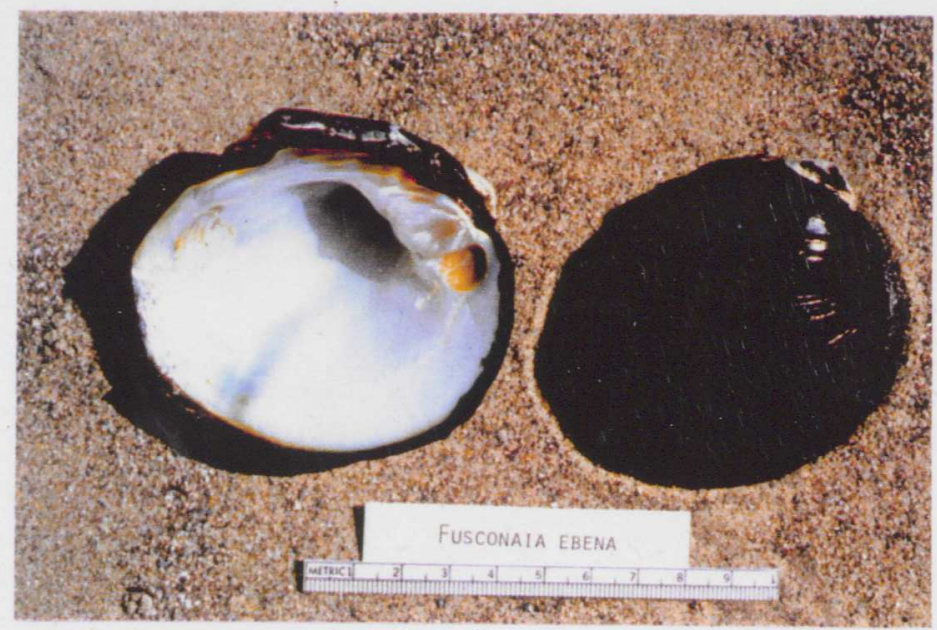

Figure A8 


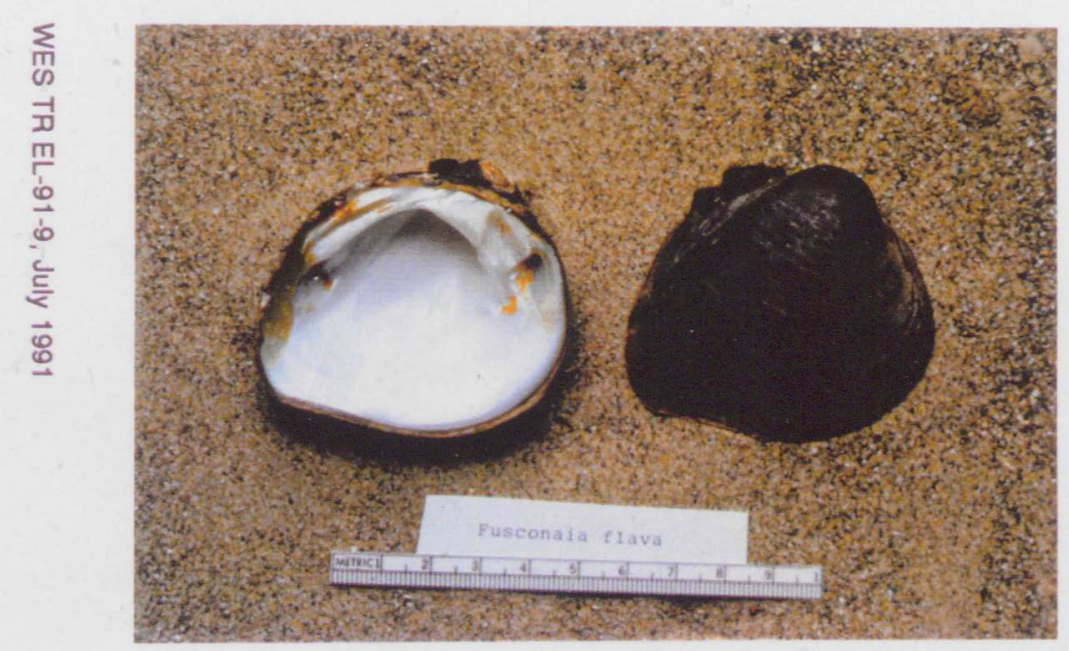

Figure A9

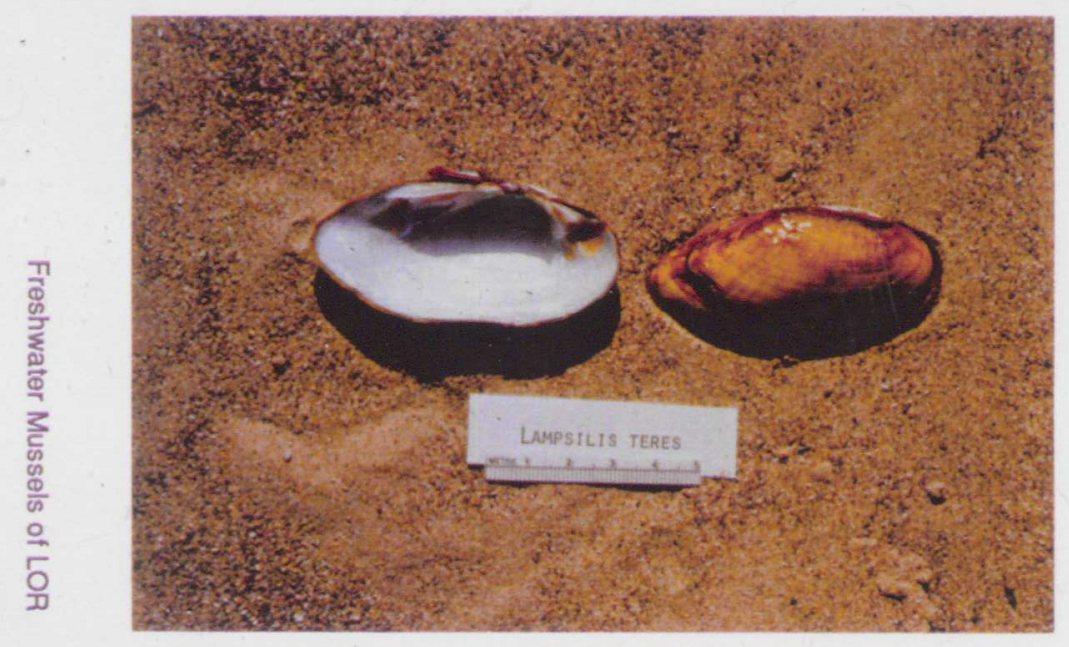

$\rightarrow$

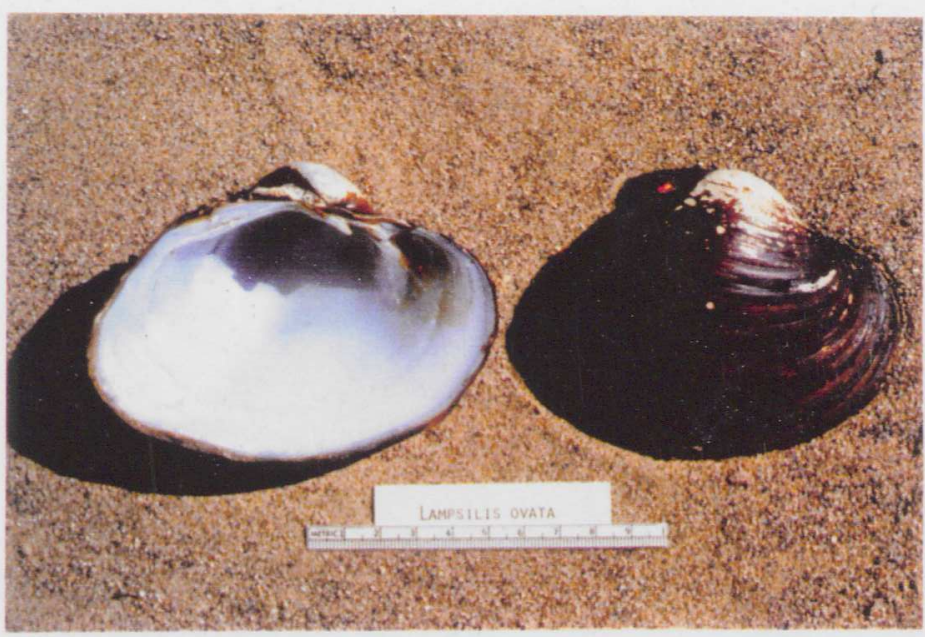

Figure A10

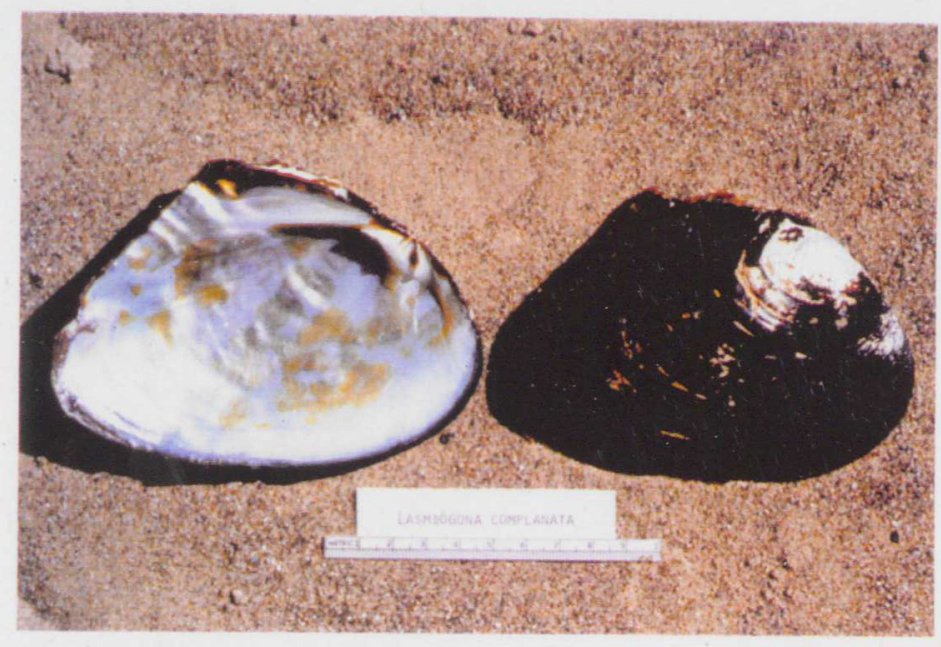

Figure A12 


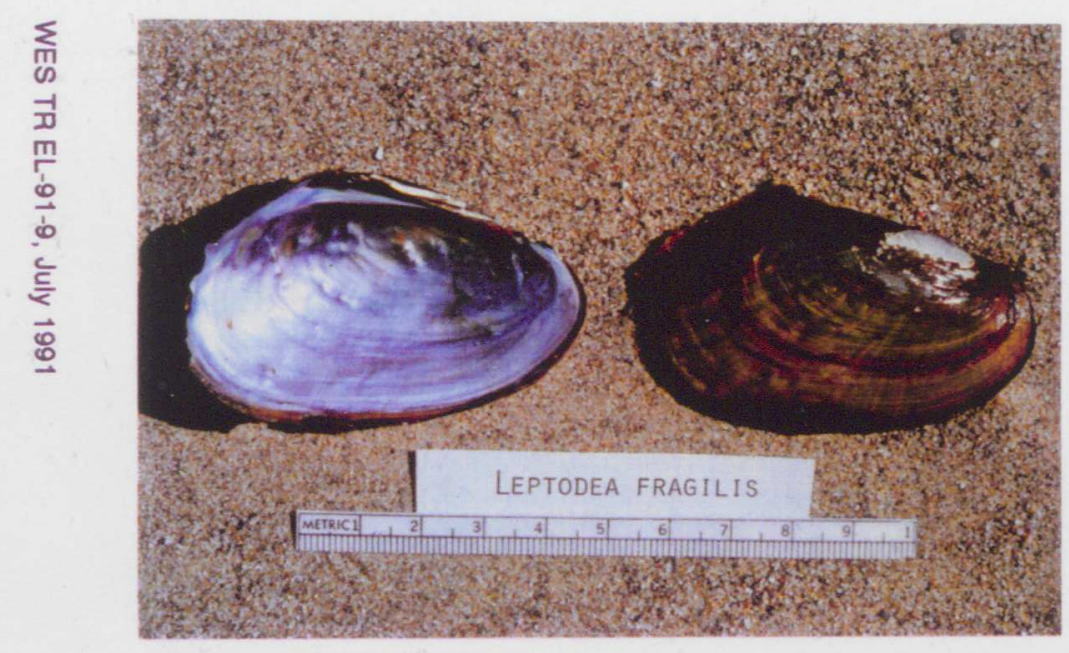

Figure A13

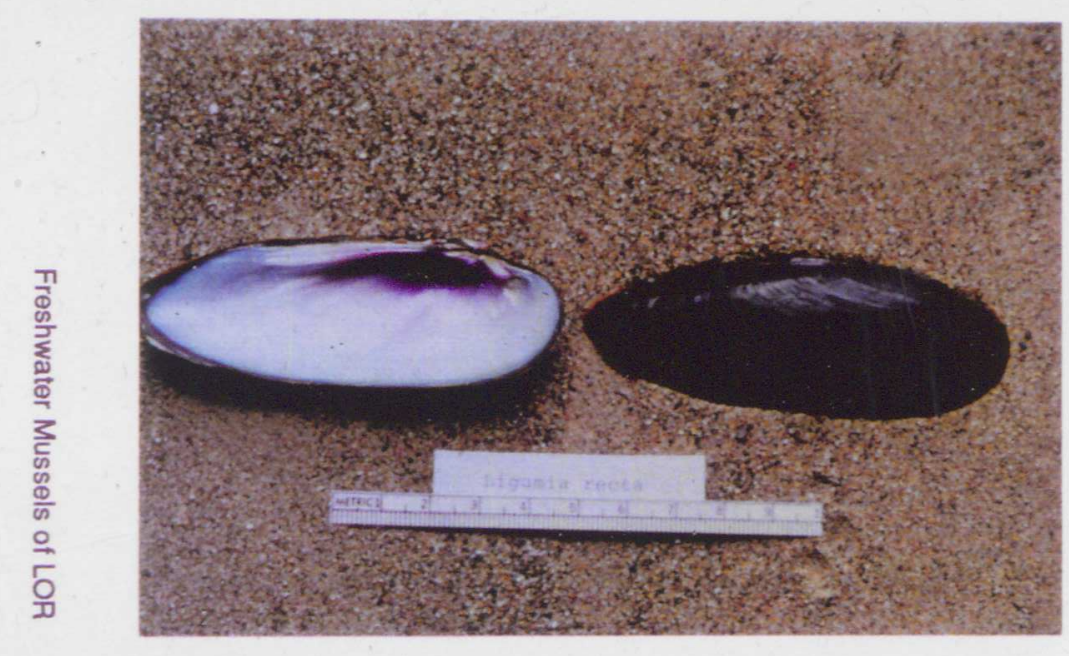

ㄱ Figure A15

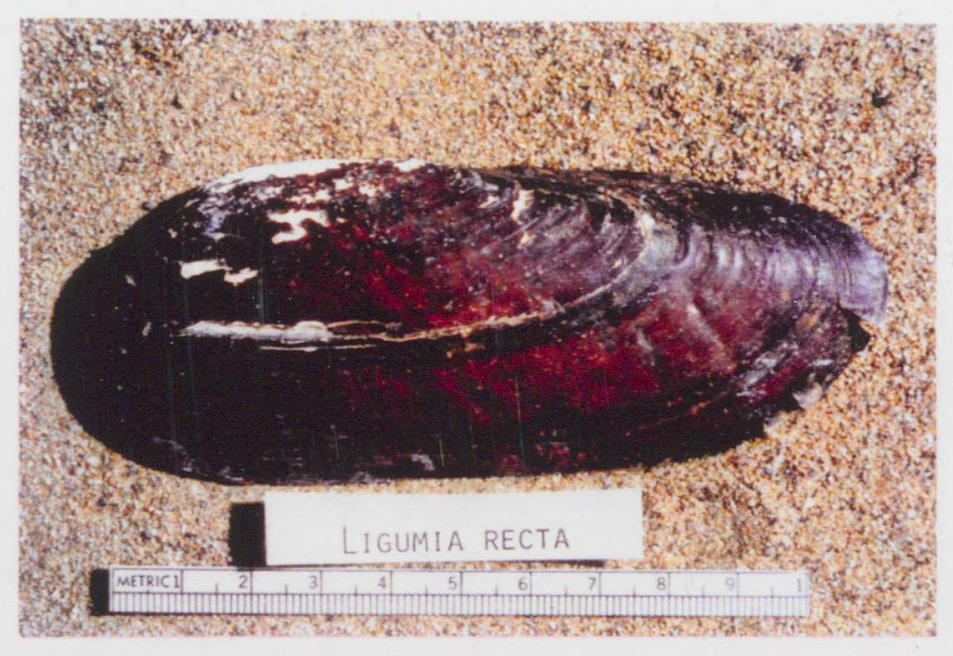

Figure A14

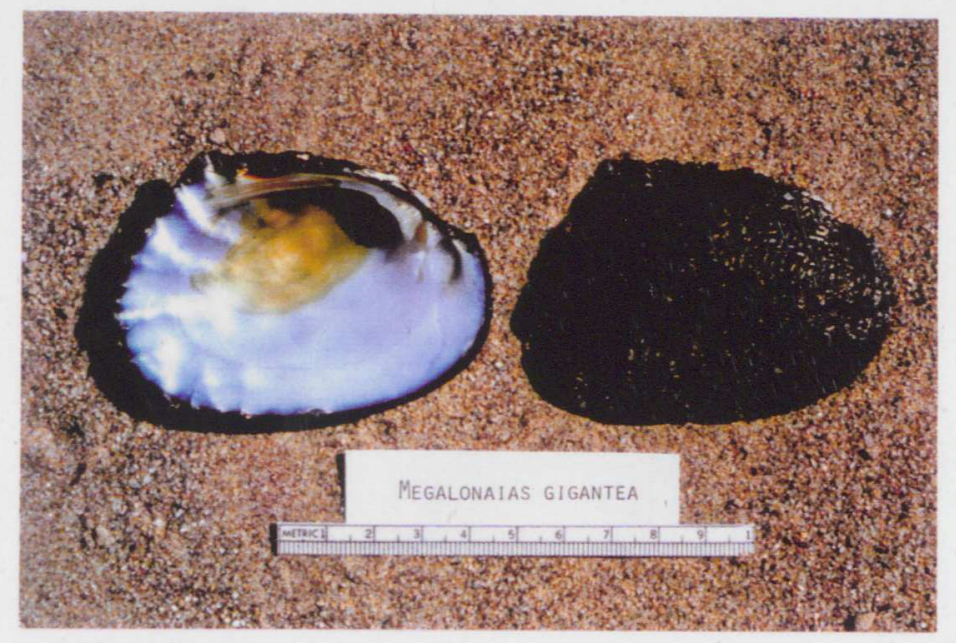

Figure A16 


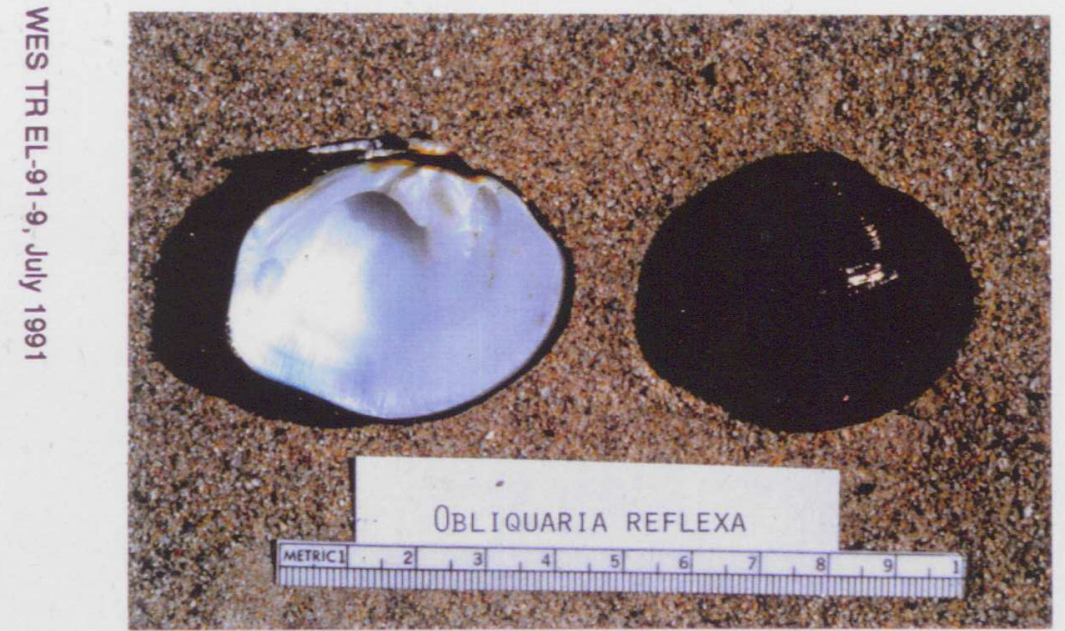

Figure A17

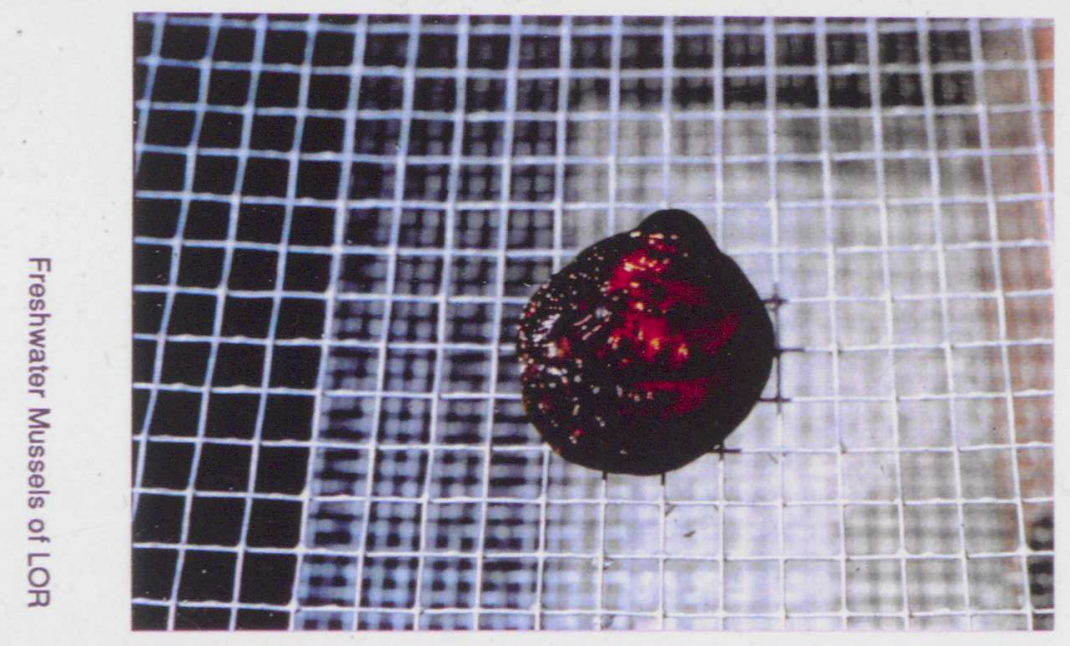

๖ Figure A19

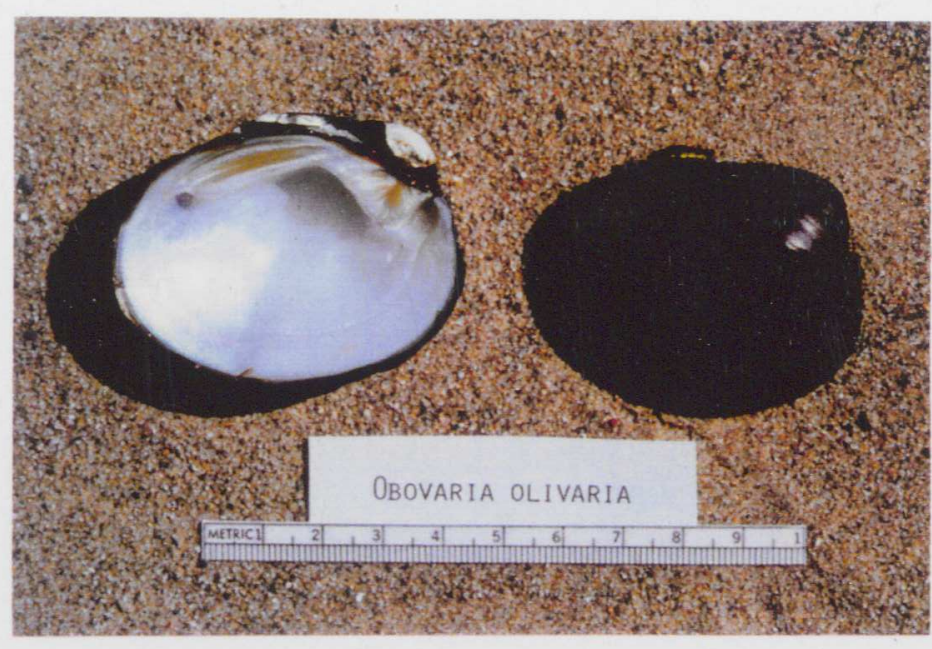

Figure A18

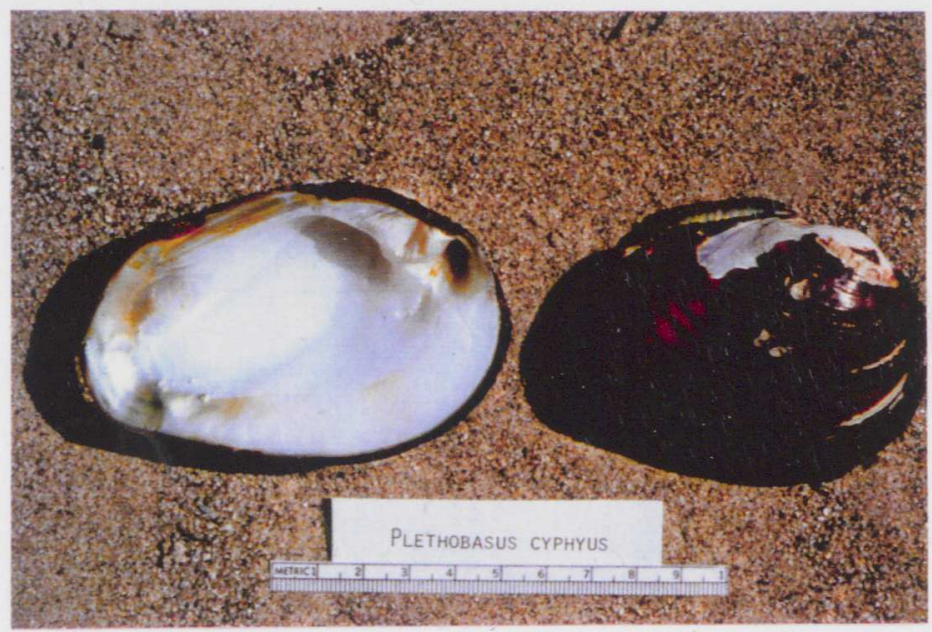

Figure A20 


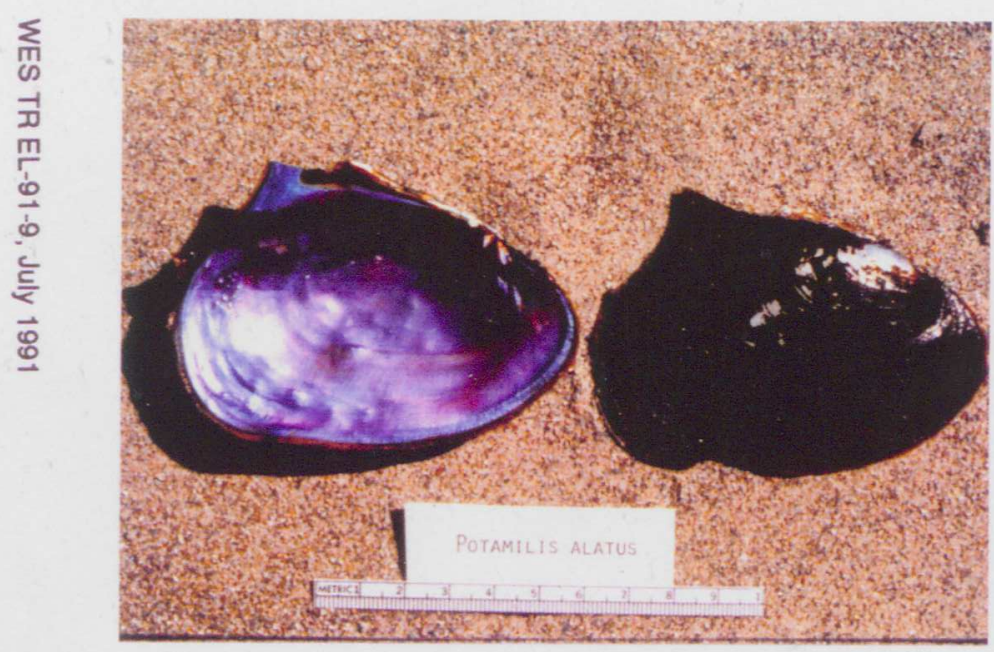

Figure A21

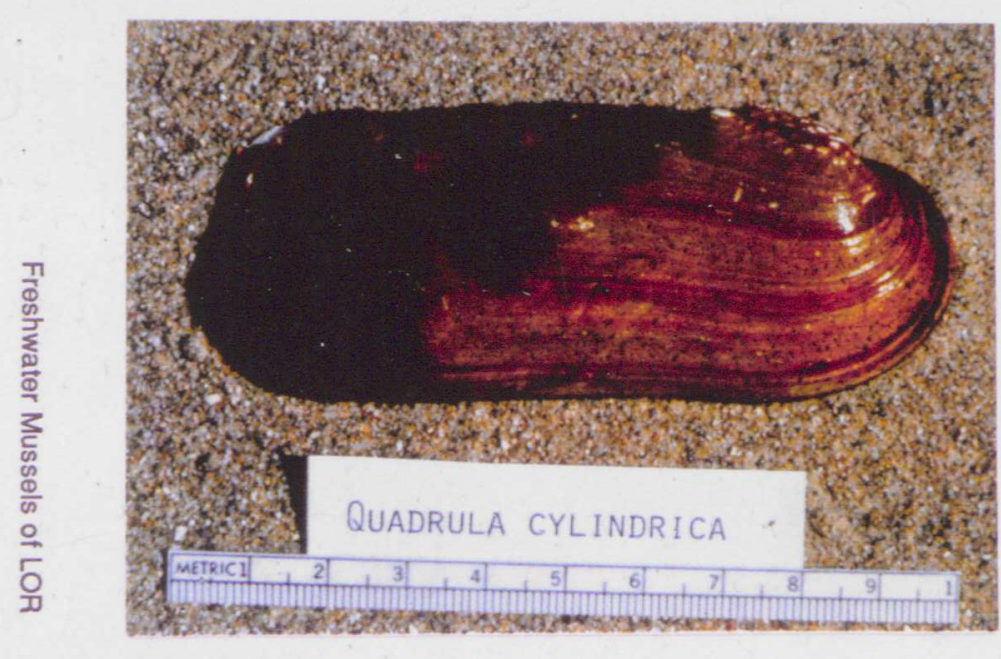

$\gtrsim \quad$ Figure A23

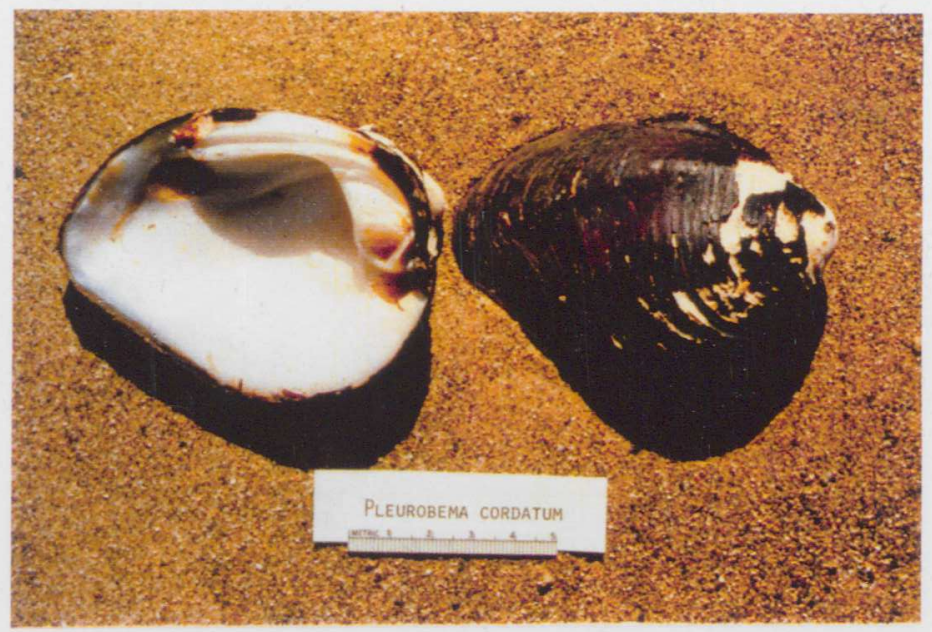

Figure A22

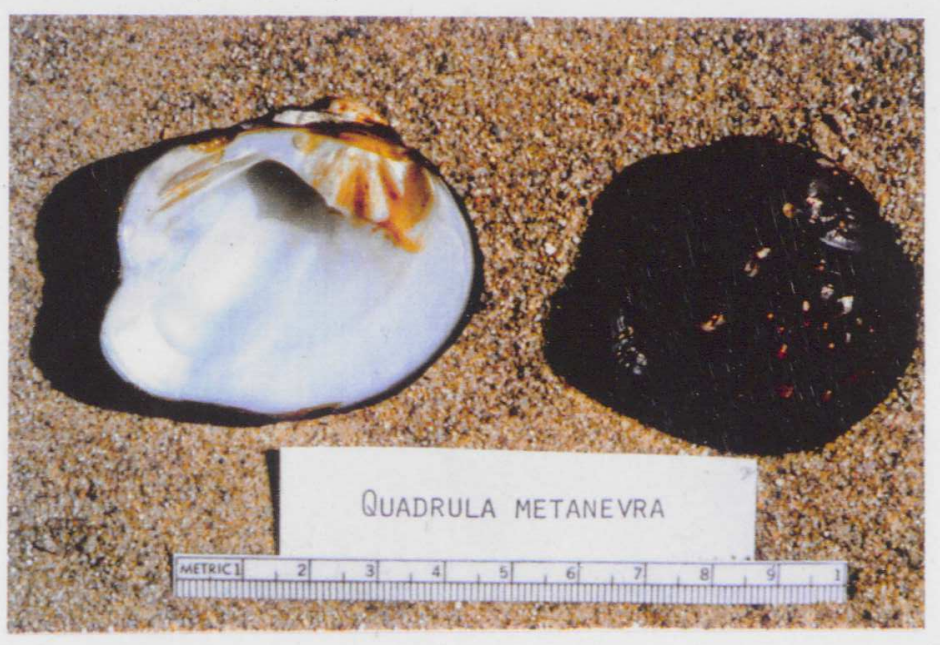

Figure A24 


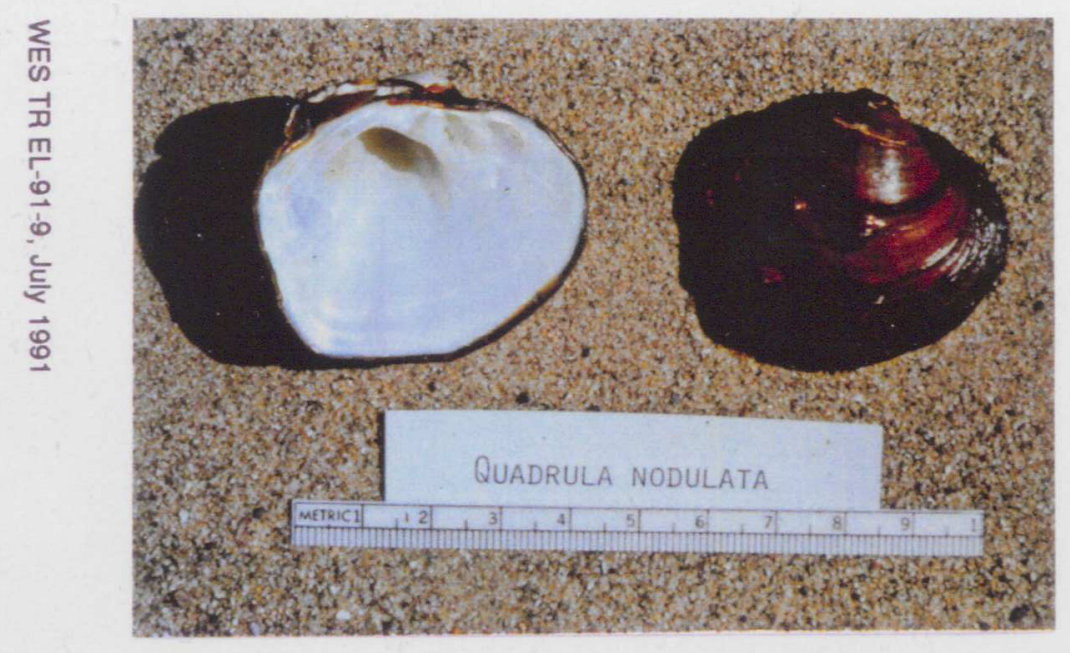

Figure A25

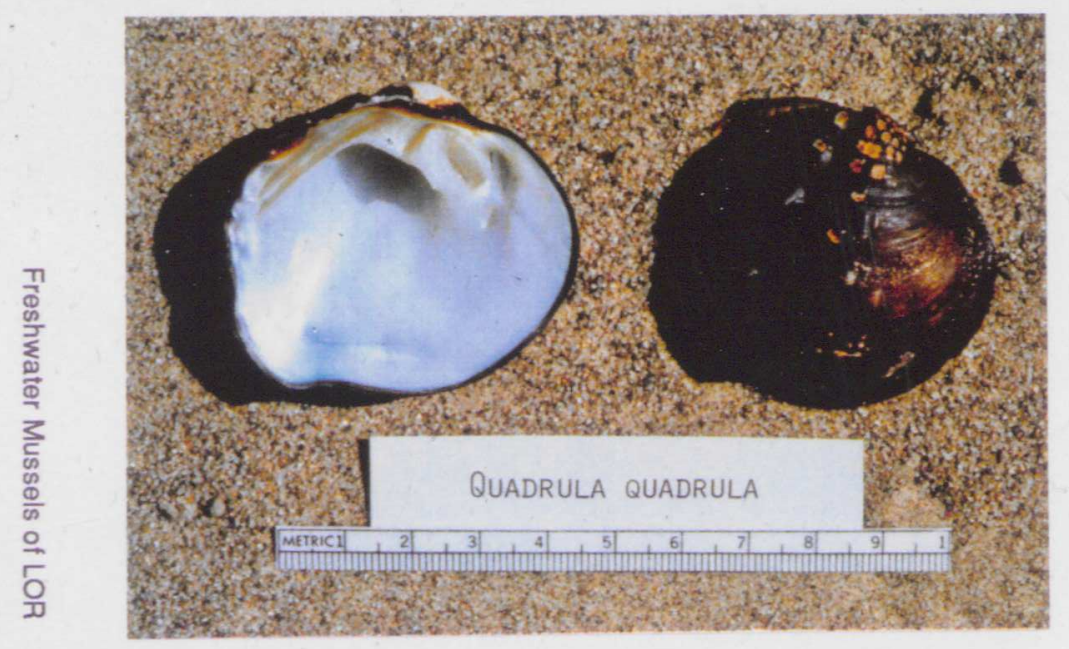

$\gg \quad$ Figure A27

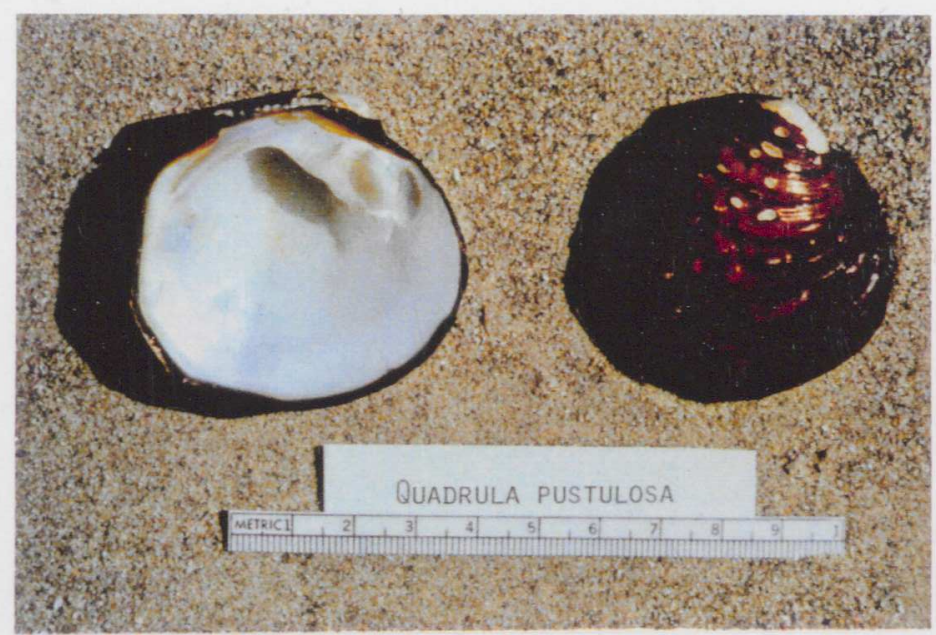

Figure A26

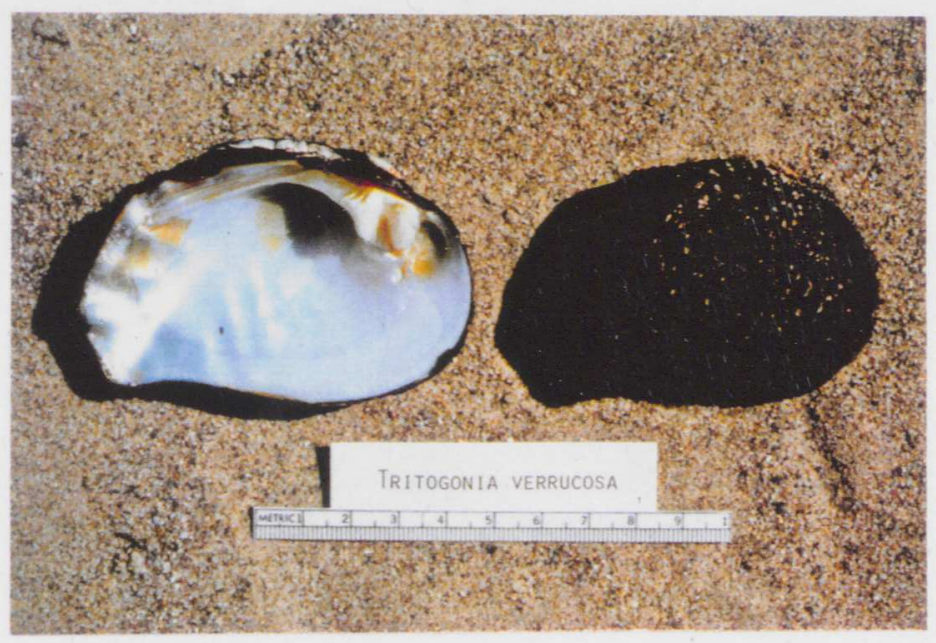

Figure A28 


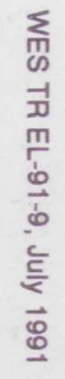

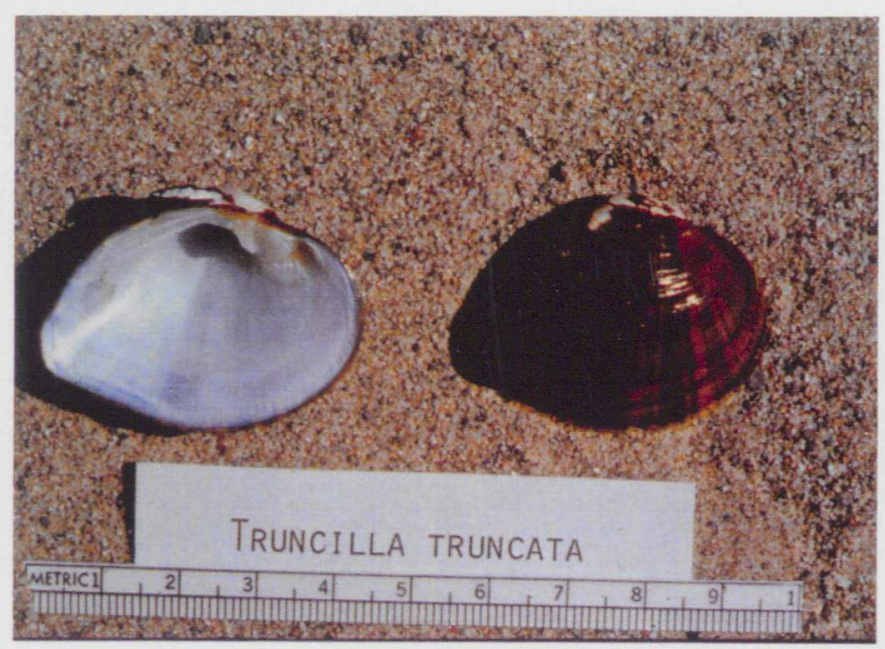

Figure A29

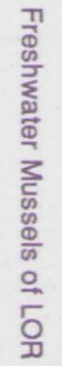


